\title{
Diversity Captured in the USDA-ARS National Plant Germplasm System Apple Core Collection
}

\author{
Briana L. Gross \\ University of Minnesota Duluth, 207 Swenson Science Building, 1035 Kirby Drive, Duluth, MN 55812 \\ Gayle M. Volk ${ }^{2}$, Christopher M. Richards, Patrick A. Reeves, and Adam D. Henk \\ USDA-ARS National Center for Genetic Resources Preservation, 1111 S. Mason Street, Fort Collins, \\ CO 80521
}

\author{
Philip L. Forsline ${ }^{1}$, Amy Szewc-McFadden, Gennaro Fazio, and C. Thomas Chao \\ USDA-ARS Plant Genetic Resources Unit, Geneva, NY 14456
}

\begin{abstract}
Additional Index words. Malus, simple sequence repeat, clonal crop
Abstract. The USDA-ARS National Plant Germplasm System Malus collection is maintained by the Plant Genetic Resources Unit (PGRU) in Geneva, NY. In the 1990s, a core subset of 258 trees was hand-selected to be representative of the grafted Malus collection. We used a combination of genotypic and phenotypic data to compare the diversity of the 198 diploid trees in the original core subset with that of $\mathbf{2 1 1 4}$ diploid trees in the grafted field collection for which data were available. The 198 trees capture 192 of the 232 total microsatellite alleles and have 78 of the 95 phenotypic characters. An addition of 67 specific individuals increases the coverage to $100 \%$ of the allelic and phenotypic character states. Several de novo core sets that capture all the allelic and phenotypic character states in 100 individuals are also provided. Use of these proposed sets of individuals will help ensure that a broad range of Malus diversity is included in evaluations that use the core subset of grafted trees in the PGRU collection.
\end{abstract}

Large field collections of plant genetic resources, although critical for many clonal and perennial crops, are expensive to maintain and can be unwieldy for research purposes. In the 1980s, Brown and colleagues described a need to identify representative subsets of larger collections. These collections could be given higher priority for evaluations and could be made widely available at multiple locations, thus increasing access to associated data for the gene bank user community (Brown, 1989; Rubenstein et al., 2006). Core collections of crops have since been developed using a number of different strategies, including selection of materials from geographic or ecological groups or selection of highly differentiated materials. These stratified sampling techniques seek to maximize allelic richness and capture the available genetic and phenotypic diversity (Schoen and Brown, 1995). Various combinations of morphology, climatic, geographic, genetic distances, and genetic diversity assessments have been implemented to develop core collections for diverse crops (Balakrishnan et al., 2000; Balfourier et al., 2007; Bisht et al., 1998; ChavarriagaAguirre et al., 1999; Franco et al., 2001, 2006; Jansen and van Hintum, 2007; Lázaro and Aguinagalde, 2006; McKhann et al., 2004; Ronfort et al., 2006; Wang et al., 2006a, 2006b, 2007). Many researchers have turned to optimization algorithms such as MSTRAT, which seek to maximize allelic and/or phenotypic richness by ensuring that the maximum number of character states is represented in the core set of individuals (Gouesnard et al., 2001). Further studies have examined the value of relying on neutral genetic markers to estimate collection diversity (Bataillon et al., 1996; Reeves et al., 2012).

Apple (Malus $\times$ domestica) is a globally produced clonal crop for which field collections play a crucial role in preserving

Received for publication 20 May 2013. Accepted for publication 10 July 2013. ${ }^{1}$ Retired.

${ }^{2}$ Corresponding author. E-mail: Gayle.Volk@ars.usda.gov. genetic diversity and providing breeding material. In particular, apple production is currently threatened by disease, pest susceptibility, suboptimal cold and heat tolerance, minimal resistance to drought and wet soils, undesirable storage and transport characteristics, and expensive production methods (Yue et al., 2012). Simultaneously, there is rising consumer demand for organic produce and heritage apple cultivars. The USDA-ARS National Plant Germplasm System (NPGS) apple collection in Geneva, NY, has key genetic resources that can be used in breeding and research programs to address the threats to apple crop production and to provide disease- and climatehardy heritage cultivars to interested growers. The grafted portion of this collection is a set of 3442 individuals maintained for their unique genotypes. These clonally maintained individuals are primarily cultivars but also include wild Malus species representatives. The trees were in an orchard that was planted on seedling rootstock when the phenotypic data for this research were collected. Since that time, the entire collection has been repropagated onto EMLA 7 rootstock. The grafted collection is complimented by a "species" collection consisting of over 3000 seedling trees grown from wild-collected seeds. The current study focuses on the grafted "clonally propagated" part of the NPGS apple collection.

Core collections have been developed for both the entire Malus grafted collection and for subsets of wild species collections using either phenotypic and/or genetic data. For example, over 1000 M. sieversii seedlings from the "species" collection that represent eight collection sites in Kazakhstan have been genotyped using microsatellite markers and evaluated for key phenotypic traits. In 2005, Volk et al. proposed two sets of 35 individuals that represent 174 and 278 trees of M. sieversii from Kazakhstan collection sites 6 and 9, respectively (Volk et al., 2005). In 2009, Richards et al. developed a third core set of 35 individuals that captures the measured genotypic and phenotypic diversity from the remaining 
Kazakhstan collection locations of $M$. sieversii (Richards et al., 2009a, 2009b). These smaller sets of individuals were designed to capture the diversity of the larger plantings so that a subset of individuals could be targeted for field maintenance as grafted clones and long-term back-up using cryopreservation technologies (Volk et al., 2005). Similarly, a core set of $27 \mathrm{M}$. orientalis individuals was proposed as a method to capture the genetic diversity represented by 776 seedling trees of $M$. orientalis in the "species" collection as measured using seven microsatellite markers (Volk et al., 2009).

In the 1990s, a set of 258 individuals was hand-selected to be a representative "core collection" of the grafted collection of apples at the Geneva, NY, repository (Supplemental Table 1). Phenotypic, genotypic, and image data are now available for most of the individuals in the core collection. These individuals have also been distributed to multiple locations, including Washington State University, the University of Illinois, and the University of Minnesota for inclusion in breeding programs as well as for horticultural trait, biotic, and abiotic resistance evaluations (Hokanson et al., 1998). Previous reports have focused on assessing the diversity and genetic relationships among accessions in the core collection (or a portion thereof) using microsatellite markers (Hokanson et al., 1998, 2001; Potts et al., 2012). In this project, we consider the phenotypic and allelic diversity of the diploid trees in the apple core collection in relation to the diversity in the grafted diploid apple collection. We assess the current diversity captured and propose additional individuals from the grafted collection that either complement or replace individuals in the current core collection so that a broader spectrum of diversity is represented.

\section{Materials and Methods}

Plant material. Most of the diploid trees in the grafted PGRU orchards were sampled for potential inclusion in the genetic analyses. Trees were genotyped at nine simple sequence repeat (SSR) loci (see below), and only diploid trees with microsatellite signatures that could be scored in a comparative manner were included in the final data set. The final data set comprised 2114 samples, also referred to as individuals or accessions, each identified with a unique PI number. Of these samples, 198 are part of the current core collection that was proposed in the 1990s (Table 1).

Phenotypic Data. Phenotypic data were collected in orchard evaluations performed in Geneva, NY. Available data were downloaded from the Genetic Resources Information Network database [GRIN (U.S. Department of Agriculture, 2012)]. The data for each accession were collected in a single growing season after the trees had reached maturity (not necessarily in the same year for all of the accessions). Continuous descriptors were placed into categories to facilitate core collection assessments. Phenotypic data were primarily related to fruit trait characteristics. Data were collected on fruit that were mature, defined as when the overcolor on the fruit was apparent. "Fruit weight" was measured as the mean weight of 10 fruit at maturity and data were classified into 50-g increments. "Fruit shape" data were classified as globose, short, flat, conical, ellipsoid, or oblong. "Fruit ground color" at maturity data used the first color descriptor of the GRIN classification: light green, green, light yellow, yellow, orange, brown, pink, red, or purple. Similarly, "overcolor pattern" was classified as blush, striped, splashed, or none. "Fruit overcolor" was measured at maturity and GRIN data were classified into the following categories: none, green, yellow, orange, brown, pink, red, dark red, and purple. "Overcolor intensity" was measured as the percent of overcolor on fruit and placed into categories. "Fruit russet" was measured as the percent of russeting on fruit and placed into categories in $10 \%$ increments between $0 \%$ and $100 \%$.

"Fruit flesh color" data were reclassified into categories using only the first digit of the numerical code representing flesh colors white, cream, green, yellow, orange, pink, red, or rose red. "Fruit flesh firmness" at maturity was classified as soft, semifirm, firm, or hard according to standards described in GRIN. "Fruit flesh oxidation" was visually measured in cut fruit after $10 \mathrm{~min}$ at room temperature. Descriptor values ranged from non-oxidizing $(0 \%$ to $1 \%)$, slightly oxidizing $(1 \%$ to $4 \%$ ), oxidizing ( $5 \%$ to $10 \%$ ), and very oxidizing (greater than $10 \%)$. "Fruit juiciness" was measured as a rating of fruit flesh juiciness based on the apple weight to apple volume (specific gravity) and recorded as a mean of five apples at maturity. Code values were very dry (less than 0.75$)$, dry $(0.76$ to 0.80$)$, medium ( 0.81 to 0.85$)$, moderately juicy $(0.86$ to 0.90$)$, and very juicy (greater than 0.90) (Young, 1914). Percent "soluble solids" were measured as the average refractometer readings from juice sampled from three fruit at full maturity. Quantitative values were placed into categories as described on GRIN. "Fruit flesh flavor" was classified qualitatively as aromatic, sweet, subacid, acid, and astringent.

Molecular DATA. Genomic DNA was extracted from leaf tissue using DNeasy 96 plant kits (Qiagen, Valencia, CA). Nine previously published SSRs [GD12, GD15, GD96, GD142, GD147, GD162, CH01h01, CH01f02, and CH02d08 (Hokanson et al., 1998; Liebhard et al., 2002)] were amplified in all samples. Primer sequences, amplicon size ranges, and annealing temperatures are listed in Gross et al. (2012a). Amplification and scoring were carried out according to Gross et al. (2012a). Briefly, polymerase chain reaction products were scored in one of two ways. Some were visualized on a slab sequencer (LI4200; LI-COR, Lincoln, NE) and digital images were manually interpreted using Saga Generation 2 software (LI-COR). Others were visualized on a capillary sequencer (ABI 3730; Applied Biosystems, Foster City, CA) and chromatograms were scored automatically and then corrected manually using GeneMarker software (SoftGenetics, State College, PA). When a single SSR locus was scored using both systems, control individuals of known genotypes were run on both systems to control for allele length differences resulting from instrumentation.

Evaluation and development of core collections. De novo core collections and amended cores were constructed using the maximization algorithm (M) of Schoen and Brown (1995) as implemented in the program MSTRAT (Gouesnard et al., 2001) with all character states of molecular and phenotypic data weighted equally. Marker data were also analyzed using a modified maximization procedure [M+ (Reeves et al., 2012)] with all character states of molecular data weighted equally. The $\mathrm{M}+$ procedure improves on MSTRAT in several ways, including the ability to discard missing data (rather than counting it as a character state), the ability to consider two alleles at a single locus jointly rather than separately, and the ability to weight loci equally rather than giving a higher weight to more diverse loci (Gouesnard et al., 2001; Reeves et al., 2012).

MSTRAT was used to construct amended cores; these cores included the current core samples with additional samples to 
Table 1. Taxonomic diversity in the grafted apple collection of the USDA-ARS Plant Genetic Resources Unit (Geneva, NY). ${ }^{\mathrm{z}}$

\begin{tabular}{|c|c|c|c|}
\hline Malus species & $\begin{array}{l}\text { Grafted diploid } \\
\text { trees included in } \\
\text { analyses (no.) }\end{array}$ & $\begin{array}{l}\text { Original core } \\
\text { collection } \\
\text { trees (no.) } \\
\end{array}$ & $\begin{array}{c}\text { Original diploid core } \\
\text { collection trees included } \\
\text { in analyses (no.) }\end{array}$ \\
\hline M. angustifolia & 18 & 2 & 2 \\
\hline M. baccata & 45 & 6 & 6 \\
\hline M. brevipes & 2 & 1 & 1 \\
\hline M. coronaria & 36 & 3 & 2 \\
\hline M. doumeri & 0 & 1 & 0 \\
\hline M. florentina & 3 & 2 & 2 \\
\hline M. floribunda & 10 & 1 & 1 \\
\hline M. fusca & 40 & 4 & 4 \\
\hline M. halliana & 10 & 3 & 3 \\
\hline M. honanensis & 2 & 2 & 2 \\
\hline M. hupehensis & 3 & 6 & 1 \\
\hline Hybrid & 298 & 37 & 35 \\
\hline M. ioensis & 35 & 5 & 4 \\
\hline M. kansuensis & 5 & 4 & 2 \\
\hline M. komarovii & 0 & 0 & 0 \\
\hline M. mandshurica & 3 & 1 & 1 \\
\hline M. ombrophila & 3 & 2 & 2 \\
\hline M. orientalis & 6 & 12 & 2 \\
\hline M. orthocarpa & 1 & 0 & 0 \\
\hline M. prattii & 4 & 3 & 3 \\
\hline M. prunifolia & 35 & 8 & 8 \\
\hline M. pumila & 11 & 2 & 2 \\
\hline M. sargentii & 6 & 1 & 0 \\
\hline M. sieversii & 166 & 28 & 10 \\
\hline M. sikkimensis & 3 & 2 & 0 \\
\hline Malus sp. & 27 & 2 & 2 \\
\hline M. spectabilis & 6 & 2 & 1 \\
\hline M. sylvestris & 15 & 7 & 7 \\
\hline M. toringo & 11 & 7 & 3 \\
\hline M. toringoides (M. bhutanica) & 3 & 4 & 1 \\
\hline M. transitoria & 2 & 4 & 2 \\
\hline M. trilobata & 0 & 1 & 0 \\
\hline M. tschonoskii & 3 & 1 & 1 \\
\hline M. $\times$ adstringens & 3 & 0 & 0 \\
\hline M. ×arnoldiana & 2 & 1 & 1 \\
\hline M. $\times$ asiatica & 16 & 4 & 4 \\
\hline M. ×astracanica & 1 & 1 & 0 \\
\hline M. $\times$ atrosanguinea & 2 & 0 & 1 \\
\hline M. $\times$ dawsoniana & 2 & 1 & 1 \\
\hline M. $\times$ domestica & 1211 & 67 & 64 \\
\hline M. $\times$ hartwigii & 5 & 1 & 1 \\
\hline M. ×magdeburgensis & 2 & 1 & 1 \\
\hline M. $\times$ micromalus & 14 & 5 & 4 \\
\hline M. $\times$ moerlandsii & 2 & 0 & 0 \\
\hline M. ×platycarpa & 2 & 1 & 0 \\
\hline M. ×purpurea & 5 & 0 & 0 \\
\hline M. ×robusta & 11 & 3 & 3 \\
\hline M. ×scheideckeri & 1 & 0 & 0 \\
\hline M. ×soulardii & 2 & 1 & 1 \\
\hline M. ×sublobata & 3 & 2 & 1 \\
\hline M. yunnanensis & 14 & 3 & 3 \\
\hline M. zhaojiaoensis & 2 & 2 & 2 \\
\hline M. zumi & 2 & 1 & 1 \\
\hline Total & 2114 & 258 & 198 \\
\hline
\end{tabular}

${ }^{\mathrm{z}}$ The number of unique diploid trees included in the genotyping analyses, the number of core collection trees in the original core collection, and the number of diploid trees in the original core collection included in the genotyping analyses are provided for each species or hybrid. maximize diversity. We allowed the program to add samples until all molecular and phenotypic characters were captured and ran 10 independent replicates of the amended core. Results for the amended core replicates were compared; samples that were present in 10 of 10 runs were considered as potential additions to the current core (Table 2; Supplemental Table 2). The modified MSTRAT program, M+, was used to generate de novo cores from the Malus main collection. As a result of computational constraints associated with the large size of the main collection, the $\mathrm{M}+$ program was run, increasing the core size by increments of 20 , until the core contained all the possible molecular and phenotypic characters; this was replicated 10 times. Full results of these runs are presented in the supplementary data (Supplemental Table 3).

General genetic diversity statistics were calculated for the 198 diploid samples of the current core, the diploid grafted collection, potential amended cores, and a representative de novo core using GenoDive (Meirmans and Van Tienderen, 2004). The number of alleles and phenotypic character states in the diploid existing core and diploid grafted collection were compared with the proposed cores to evaluate the percentage of variation captured (Table 3).

\section{Results}

CORE COLLECTION REPRESENTATION. In 2011, the PGRU grafted apple collection included 3442 individuals representing 51 species or named hybrids. The original core collection is represented by 258 individuals from 46 species. Of these, 67 individuals are $M . \times$ domestica. The constraints resulting from ploidy levels and missing data left 2114 diploid individuals from the grafted collection included in the analysis. All but 169 of the 2114 diploid grafted collection individuals had phenotypic data available, and all but eight of the 198 current core diploid individuals had phenotypic data available.

We used principal component analyses to visualize how well the 
Table 2. Potential additional apple accessions that could be amended to the original apple core collection to increase its genetic and phenotypic diversity. ${ }^{\mathrm{z}}$

\begin{tabular}{|c|c|c|c|c|c|c|}
\hline In 10 of 10 & $\begin{array}{l}\text { Addition to existing core } \\
\text { for improved diversity }\end{array}$ & PI no. & Genus & Species & Cultivar & Original source \\
\hline $\mathrm{x}$ & $\mathrm{x}$ & 392301 & Malus & baccata & & China \\
\hline $\mathrm{x}$ & $\mathrm{x}$ & 588907 & Malus & baccata & Himalaica & China \\
\hline $\mathrm{x}$ & $\mathrm{x}$ & 590057 & Malus & baccata & & China \\
\hline $\mathrm{x}$ & $\mathrm{x}$ & 613925 & Malus & prattii & & China \\
\hline $\mathrm{x}$ & $\mathrm{x}$ & 589162 & Malus & coronaria & Glabrata & United States \\
\hline $\mathrm{x}$ & $\mathrm{x}$ & 589423 & Malus & coronaria & & United States \\
\hline $\mathrm{x}$ & $\mathrm{x}$ & 123733 & Malus & domestica & Bedan des parts & France \\
\hline $\mathrm{x}$ & $\mathrm{x}$ & 134668 & Malus & domestica & Pomme Cloche & Germany \\
\hline $\mathrm{x}$ & $\mathrm{x}$ & 162062 & Malus & domestica & Daux Belan & France \\
\hline $\mathrm{x}$ & $\mathrm{x}$ & 245048 & Malus & domestica & Belle Fleur Rouge & France \\
\hline $\mathrm{x}$ & $\mathrm{x}$ & 264689 & Malus & domestica & Djulabia & Serbia \\
\hline $\mathrm{x}$ & $\mathrm{x}$ & 589018 & Malus & domestica & Cimitiere & The Netherlands \\
\hline $\mathrm{x}$ & $\mathrm{x}$ & 590136 & Malus & domestica & Reinette de Cuzy & France \\
\hline $\mathrm{x}$ & $\mathrm{x}$ & 264693 & Malus & domestica & Sumatovka & Serbia \\
\hline $\mathrm{x}$ & $\mathrm{x}$ & 322714 & Malus & domestica & Kandil Kitaika & former Soviet Union \\
\hline $\mathrm{x}$ & $\mathrm{x}$ & 589080 & Malus & domestica & Dermen Winesap 2-4-4 & United States \\
\hline $\mathrm{x}$ & $\mathrm{x}$ & 613814 & Malus & domestica & San Jacinto & United States \\
\hline $\mathrm{x}$ & $\mathrm{x}$ & 589099 & Malus & domestica & Perrine Yellow Transparent & United States \\
\hline $\mathrm{x}$ & $\mathrm{x}$ & 141362 & Malus & Hybrid & James Kirk & United Kingdom \\
\hline $\mathrm{x}$ & $\mathrm{x}$ & 296775 & Malus & Hybrid & Ottawa 541 & Canada \\
\hline $\mathrm{x}$ & $\mathrm{x}$ & 588887 & Malus & Hybrid & Profusion & The Netherlands \\
\hline $\mathrm{x}$ & $\mathrm{x}$ & 588915 & Malus & Hybrid & Beverly & \\
\hline $\mathrm{x}$ & $\mathrm{x}$ & 588984 & Malus & Hybrid & Kensib & United States \\
\hline $\mathrm{x}$ & $\mathrm{x}$ & 589058 & Malus & Hybrid & September & United States \\
\hline $\mathrm{x}$ & $\mathrm{x}$ & 589282 & Malus & Hybrid & RMJ 105 & \\
\hline $\mathrm{x}$ & $\mathrm{x}$ & 613799 & Malus & micromalus & & \\
\hline $\mathrm{x}$ & $\mathrm{x}$ & 590096 & Malus & pumila & & \\
\hline $\mathrm{x}$ & $\mathrm{x}$ & 657107 & Malus & sieversii & & Kazakhstan \\
\hline $\mathrm{x}$ & $\mathrm{x}$ & 613989 & Malus & sieversii & & Kazakhstan \\
\hline $\mathrm{x}$ & $\mathrm{x}$ & 629316 & Malus & sieversii & & Tajikistan \\
\hline $\mathrm{x}$ & $\mathrm{x}$ & 613865 & Malus & sylvestris & & Macedonia \\
\hline $\mathrm{x}$ & $\mathrm{x}$ & 613870 & Malus & sylvestris & & Macedonia \\
\hline $\mathrm{x}$ & $\mathrm{x}$ & 590101 & Malus & toringo & Toringo Crab Apple & Japan \\
\hline $\mathrm{x}$ & $\mathrm{x}$ & 613860 & Malus & toringo & & Korea \\
\hline $\mathrm{x}$ & $\mathrm{x}$ & 590067 & Malus & yunnanensis & & China \\
\hline \multirow[t]{22}{*}{$\mathrm{x}$} & $\mathrm{x}$ & 590113 & Malus & yunnanensis & Yunnan Crab Apple & China \\
\hline & $\mathrm{x}$ & 589769 & Malus & angustifolia & & United States \\
\hline & $\mathrm{x}$ & 589770 & Malus & angustifolia & & United States \\
\hline & $\mathrm{x}$ & 613879 & Malus & angustifolia & & United States \\
\hline & $\mathrm{x}$ & 104034 & Malus & domestica & Renetta Dorata & Italy \\
\hline & $\mathrm{x}$ & 247314 & Malus & domestica & Frequin Lacaille & France \\
\hline & $\mathrm{x}$ & 589196 & Malus & domestica & Crow Egg & United States \\
\hline & $\mathrm{x}$ & 589242 & Malus & domestica & Pomme Grise & Canada \\
\hline & $\mathrm{x}$ & 589657 & Malus & domestica & Crawley Beauty & United Kingdom \\
\hline & $\mathrm{x}$ & 148478 & Malus & domestica & Jewel & United Kingdom \\
\hline & $\mathrm{x}$ & 306321 & Malus & domestica & Gibbs Golden Gauge & United Kingdom \\
\hline & $\mathrm{x}$ & 383513 & Malus & domestica & Korobovka & Russia \\
\hline & $\mathrm{x}$ & 590157 & Malus & domestica & Hudson's Golden Gem & United States \\
\hline & $\mathrm{x}$ & 590181 & Malus & domestica & Tahir 3-1 & \\
\hline & $\mathrm{x}$ & 589909 & Malus & domestica & York & United States \\
\hline & $\mathrm{x}$ & 590036 & Malus & fusca & & Canada \\
\hline & $\mathrm{x}$ & 590091 & Malus & halliana & & China \\
\hline & $\mathrm{x}$ & 589456 & Malus & Hybrid & Evelyn & United States \\
\hline & $\mathrm{x}$ & 589629 & Malus & Hybrid & Chance & United States \\
\hline & $\mathrm{x}$ & 589241 & Malus & ioensis & Prairie Rose & United States \\
\hline & $\mathrm{x}$ & 589406 & Malus & ioensis & & United States \\
\hline & & & & & & Continued next page \\
\hline
\end{tabular}


Table 2. Continued.

\begin{tabular}{|c|c|c|c|c|c|c|}
\hline In 10 of 10 & $\begin{array}{l}\text { Addition to existing core } \\
\text { for improved diversity }\end{array}$ & PI no. & Genus & Species & Cultivar & Original source \\
\hline & $\mathrm{x}$ & 590004 & Malus & ioensis & & United States \\
\hline & $\mathrm{x}$ & 613892 & Malus & ioensis & & United States \\
\hline & $\mathrm{x}$ & 657018 & Malus & sieversii & & Kazakhstan \\
\hline & $\mathrm{x}$ & 657041 & Malus & sieversii & & Kazakhstan \\
\hline & $\mathrm{x}$ & 589748 & Malus & toringo & & \\
\hline & $\mathrm{x}$ & 589866 & Malus & $\times$ hartwigii & & Latvia \\
\hline & $\mathrm{x}$ & 589016 & Malus & ×purpurea & Aldenhamensis & \\
\hline & $\mathrm{x}$ & 589755 & Malus & $\times$ sublobata & & \\
\hline
\end{tabular}

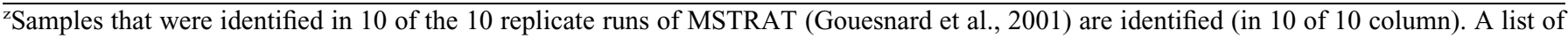
accessions identified from a single MSTRAT run that constitutes a core collection that fully captures the molecular and phenotypic diversity is provided.

Table 3. Diversity retained in diploid core collections for the grafted Geneva, NY, Plant Genetic Resources Unit Malus collection using several core assembly strategies. ${ }^{z}$

\begin{tabular}{lcccccr}
\hline & $\begin{array}{c}\text { Samples } \\
\text { (no.) }\end{array}$ & $\begin{array}{c}\text { Avg alleles } \\
\text { (no./locus) }\end{array}$ & $\begin{array}{c}\text { Total allele } \\
\text { (no.) }\end{array}$ & $\begin{array}{c}\text { Total alleles } \\
(\%)\end{array}$ & $\begin{array}{c}\text { Total phenotypic } \\
\text { characters (no.) }\end{array}$ & $\begin{array}{c}\text { Total phenotypic } \\
\text { characters (\%) }\end{array}$ \\
\hline Core & 198 & 21.3 & 192 & 83 & 78 & 82 \\
Core+36 & 234 & 24.6 & 221 & 95 & 85 & 89 \\
Core+67 & 265 & 25.8 & 232 & 100 & 100 & 95 \\
De novo core & 100 & 25.8 & 232 & 100 & 95 & 100 \\
Main collection & 2114 & 25.8 & 232 & 100
\end{tabular}

${ }^{\mathrm{z}}$ Percent total alleles was calculated by taking the number of total alleles and dividing it by the number alleles in the main collection.

core sets capture the diversity in multidimensional space represented by the grafted collection. The principal component analyses included samples for which complete genotypes were available: 103 core collection individuals and a total of 1415 individuals from the grafted collection. Although this analysis only visualized $50 \%$ of the core and $66 \%$ of the total collection, we feel that this is an unbiased sample and allows us to evaluate how well the core collection represents the larger set of genotypes. Regressing the first two principal components (accounting for $38 \%$ of the variance) shows a broad overlap (Fig. 1). When visualized as a graph, the threedimensional plot with the first three principal components is a cloud of points with no obvious divisions and the core selections appear to be randomly distributed within the cloud. The first 11 principal components account for $80 \%$ of the variation (data not shown).

Core COllections. Our results from both the MSTRAT and M+ programs indicate that a smaller core collection may be sufficient to capture the molecular diversity documented using the nine SSR loci and the phenotypic diversity described by the 13 selected fruit character traits. Entirely new core sets were identified that capture the complete molecular and phenotypic diversity with 100 samples (Table 3; Supplemental Table 3). If this approach were to be taken, several of the individuals that are currently in the core collection would be retained. An average

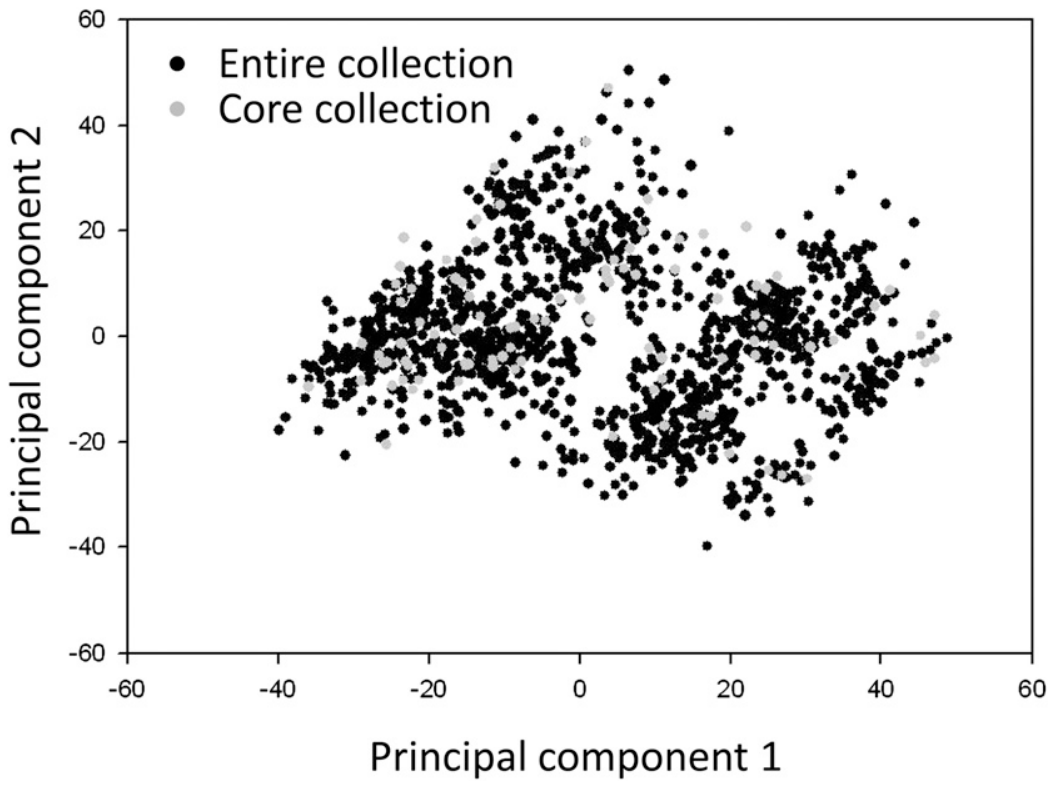

Fig. 1. Principal component analysis visualizing the first two principal components (accounting for $38 \%$ of the variance) of 103 core collection individuals (gray) and 1415 grafted Malus individuals (black) for which complete genotypes were available.

of 15.4 (ranging from 13 to 17) samples were present in both the current core collection and the de novo core sets, and eight of these samples were present in both the current core and all 10 de novo replicates (Supplemental Table 3).

Alternatively, the current core could be amended with an additional 67 samples to capture $100 \%$ of the measured 
molecular and phenotypic diversity or an additional 36 individuals to capture $95 \%$ of the molecular and $89 \%$ of the phenotypic variation (Tables 2 and 3). Because this analysis does not include polyploid individuals (either in the core or main collection), additional polyploid samples with unique phenotypic characteristics could be selected from the Geneva collections to complement the core sets identified in these analyses.

\section{Discussion}

The genetic composition of the Malus core collection, based on SSR analyses, has been previously published. Studies revealed that eight or nine SSR markers differentiate many of the collection accessions with potential "duplicates" or "sports" being the exceptions (Gross et al., 2012b; Hokanson et al., 1998). High levels of allelic diversity were present within the original core collection materials (Hokanson et al., 2001; Potts et al., 2012). To our knowledge, however, none of the previous research considered the extent to which the diversity in the grafted PGRU apple collection was captured in the original core collection. We used both molecular and phenotypic traits to assess the diversity of the core collection in relation to a larger portion of the grafted collection. Realizing that the original core collection has been used in multiple plantings and research projects, we thought it prudent to identify sets of individuals that could be added to existing projects or locations that wish to enhance the diversity of their research collections (Table 2). Future projects, however, may choose to make use of a smaller core collection that captures the diversity of the diploid accessions in the main collection with 100 individuals. The identity of the members of the new core sets is provided (Supplemental Table 3).

The phenotypic data available for the MSTRAT analyses are limited by the fact that they are collected from a single individual in a single season. The data are primarily categorical and have been broadly classified. These data were used as additional information to aid in the selection of core collections. Because the categories were broadly defined, it is likely that many of the traits would be classified similarly in subsequent years.

A germplasm collection can potentially be represented by multiple core collections. These core collections may be identified based on geographical, molecular, or phenotypic diversity. Given the diverse user community that is served by the PGRU apple collection, it is reasonable to have core collections that are tailored to specific portions of the collection. For example, previously proposed core sets for the close wild relatives of apple, $M$. sieversii and $M$. orientalis, are available for in-depth analyses of the diversity within these species. $M$. sieversii is represented by three core collections selected from seedlings obtained from unique habitats in Kazakhstan.

The core collections herein are designed to be representative of the large, multispecies, grafted collection of trees at the PGRU. As a result of the complications resulting from obtaining reliable SSR data for polyploid individuals, only diploid individuals were used in our analyses. This reduced the number of individuals in our data sets from 258 in the original core to 198 and from 3442 in the grafted collection (as of 2011) to 2114. When just these diploid accessions are considered, the original core collection captures $\approx 83 \%$ of the measured diversity in the grafted collection in $\approx 10 \%$ of the individuals. The newly proposed cores of 100 individuals capture $100 \%$ of the measured diversity in $\approx 5 \%$ of the individuals (Table 3). Additional polyploid individuals could be selected to complement the core collections that have been proposed for the diploid accessions.

MSTRAT has been used extensively to identify core sets of individuals that capture the diversity of plant collections (Balfourier et al., 2007; Ellwood et al., 2006; Jansen and van Hintum, 2007; McKhann et al., 2004). MSTRAT has the advantage of allowing the inclusion of both phenotypic and genotypic categorical data sets that are very large. MSTRAT also lets the user "lock-in" certain individuals that already exist in core sets and identify complimentary individuals that capture more diversity, thus producing an amended core (Gouesnard et al., 2001). However, the current program includes missing data as a character state and considers the two alleles present at a particular diploid locus independently rather than considering them jointly (i.e., with MSTRAT, an allele would need to occur at both positions in a locus rather than only occurring once in the data set). The program $\mathrm{M}+$ does not currently have the "lock-in" feature nor does it accept phenotypic data but does overcome the missing data and independent loci drawbacks of MSTRAT (Reeves et al., 2012). Both programs were used in our analyses to propose improved core sets based on the available data.

\section{Conclusion}

Large field collections are crucial to maintaining diversity in clonal and perennial crops, but these same collections can be unwieldy for researchers to evaluate or use as a result of their size. Core collections can streamline research that seeks to evaluate genetic or phenotypic diversity and provide a gateway into the collection for plant breeders screening for traits of interest. Although core collections can potentially be based on any number of different characters, it is reasonable to strive for full representation of the documented genetic and phenotypic diversity found in the main collection. We have proposed both a new 100 individual core and an additional 67 individuals that can be used to bring the current core up to $100 \%$ representation of the grafted collection. These collections can be supplemented with representatives having traits that were not measured in this study such as differing ploidy levels and geographic origins.

\section{Literature Cited}

Balakrishnan, R., N.V. Nair, and T.V. Sreenivasan. 2000. A method for establishing a core collection of Saccharum officinarum L. germplasm based on quantitative-morphological data. Genet. Resources Crop Evol. 47:1-9.

Balfourier, F., V. Roussel, P. Strelchenko, F. Exbrayat-Vinson, P. Sourdille, G. Boutet, J. Koenig, C. Ravel, O. Mitrofanova, M. Beckert, and G. Charmet. 2007. A worldwide bread wheat core collection arrayed in a 384-well plate. Theor. Appl. Genet. 114:1265-1275.

Bataillon, T.M., J.L. David, and D.J. Schoen. 1996. Neutral genetic markers and conservation genetics: Simulated germplasm collections. Genetics 144:409-417.

Bisht, I.S., R.K. Mahajan, T.R. Loknathan, and R.C. Agrawal. 1998. Diversity in Indian sesame collection and stratification of germplasm accessions in different diversity groups. Genet. Resources Crop Evol. 45:325-335.

Brown, A.H.D. 1989. The case for core collections, p. 136-156. In: Brown, A.H.D., O.H. Frankel, D.R. Marshall, and J.T. Williams 
(eds.). The use of plant genetic resources. Cambridge Univ. Press, New York, NY.

Chavarriaga-Aguirre, P., M.M. Maya, J. Tohme, M.C. Duque, C. Iglesias, M.W. Bonierbale, S. Kresovich, and G. Kochert. 1999. Using microsatellites, isozymes and AFLPs to evaluate genetic diversity and redundancy in the cassava core collection and to assess the usefulness of DNA-based markers to maintain germplasm collections. Mol. Breed. 5:263-273.

Ellwood, S.R., N.K. D'Souza, L.G. Kamphuis, T.I. Burgess, R.M. Nair, and R.P. Oliver. 2006. SSR analysis of the Medicago truncatula SARDI core collection reveals substantial diversity and unusual genotype dispersal throughout the Mediterranean basin. Theor. Appl. Genet. 112:977-983.

Franco, J., J. Crossa, J.M. Ribaut, J. Betran, M.L. Warburton, and M. Khairallah. 2001. A method for combining molecular markers and phenotypic attributes for classifying plant genotypes. Theor. Appl. Genet. 103:944-952.

Franco, J., J. Crossa, M.L. Warburton, and S. Taba. 2006. Sampling strategies for conserving maize diversity when forming core subsets using genetic markers. Crop Sci. 46:854-864.

Gouesnard, B., T.M. Bataillon, G. Decoux, C. Rozale, D.J. Schoen, and J.L. David. 2001. MSTRAT: An algorithm for building germplasm core collections by maximizing allelic or phenotypic richness. J. Hered. 92:93-94.

Gross, B.L., A.D. Henk, P.L. Forsline, C.M. Richards, and G.M. Volk. 2012a. Identification of interspecific hybrids among domesticated apple and its wild relatives. Tree Genet. Genomes 8:1223-1235.

Gross, B.L., G.M. Volk, C.M. Richards, P.L. Forsline, G. Fazio, and C.T. Chao. 2012b. Identification of 'duplicate' accessions within the USDA-ARS National Plant Germplasm System Malus collection. J. Amer. Soc. Hort. Sci. 137:333-342.

Hokanson, S.C., W.F. Lamboy, A.K. Szewc-McFadden, and J.R. McFerson. 2001. Microsatellite (SSR) variation in a collection of Malus (apple) species and hybrids. Euphytica 118:281-294.

Hokanson, S.C., A.K. Szewc-McFadden, W.F. Lamboy, and J.R. McFerson. 1998. Microsatellite (SSR) markers reveal genetic identities, genetic diversity and relationships in a Malus $\times$ domestica Borkh. core subset collection. Theor. Appl. Genet. 97:671-683.

Jansen, J. and T. van Hintum. 2007. Genetic distance sampling: A novel sampling method for obtaining core collections using genetic distances with an application to cultivated lettuce. Theor. Appl. Genet. 114:421-428.

Lázaro, A. and I. Aguinagalde. 2006. Genetic variation among Spanish pea landraces revealed by inter simple sequence repeat (ISSR) markers: Its application to establish a core collection. J. Agr. Sci. 144:53-61.

Liebhard, R., L. Gianfranceschi, B. Koller, C.D. Ryder, R. Tarchini, E. Van de Weg, and C. Gessler. 2002. Development and characterization of 140 new microsatellites in apple (Malus $\times$ domestica Borkh.). Mol. Breed. 10:217-241.

McKhann, H.I., C. Camilleri, A. Bérard, T. Bataillon, J.L. David, X. Reboud, V. Le Corre, C. Caloustian, I.G. Gut, and D. Brunel. 2004. Nested core collections maximizing genetic diversity in Arabidopsis thaliana. Plant J. 38:193-202.

Meirmans, P.G. and P.H. Van Tienderen. 2004. GENOTYPE and GENODIVE: Two programs for the analysis of genetic diversity of asexual organisms. Mol. Ecol. Notes 4:792-794.
Potts, S.M., Y. Han, M.A. Khan, M.M. Kushad, A.L. Rayburn, and S.S. Korban. 2012. Genetic diversity and characterization of a core collection of Malus germplasm using simple sequence repeats (SSRs). Plant Mol. Biol. Rpt. 30:827-837.

Reeves, P.A., L.W. Panella, and C.M. Richards. 2012. Retention of agronomically important variation in germplasm core collections: Implications for allele mining. Theor. Appl. Genet. 124:1155-1171. Richards, C.M., G.M. Volk, P.A. Reeves, A.A. Reilley, A.D. Henk, P.L. Forsline, and H.S. Aldwinckle. 2009a. Selection of stratified core sets representing wild apple (Malus sieversii). J. Amer. Soc. Hort. Sci. 134:229-235.

Richards, C.M., G.M. Volk, A.A. Reilley, A.D. Henk, D.R. Lockwood, P.A. Reeves, and P.L. Forsline. 2009b. Genetic diversity and population structure in Malus sieversii, a wild progenitor species of domesticated apple. Tree Genet. Genomes 5:339-347.

Ronfort, J., T. Bataillon, S. Santoni, M. Delalande, J.L. David, and J.-M. Prosperi. 2006. Microsatellite diversity and broad scale geographic structure in a model legume: Building a set of nested core collection for studying naturally occurring variation in Medicago truncatula. BMC Plant Biol. 6:28.

Rubenstein, K.D., M. Smale, and M.P. Widrlechner. 2006. Demand for genetic resources and the U.S. National Plant Germplasm System. Crop Sci. 46:1021-1031.

Schoen, D.J. and A.H.D. Brown. 1995. Maximising genetic diversity in core collections of wild relatives of crop species, p. 55-76. In: Hodgkin, T., A.H.D. Brown, T.J.L van Hintum, and E.A.V. Morales (eds.). Core collections of plant genetic resources. Wiley-Sayce, Rome, Italy.

U.S. Department of Agriculture. 2012. National genetic resources program. Germplasm resources information network (GRIN). 3 Dec. 2012. <http://www.ars-grin.gov/cgi-bin/npgs/html/>.

Volk, G.M., C.M. Richards, A.D. Henk, A.A. Reilley, P.A. Reeves, P.L. Forsline, and H.S. Aldwinckle. 2009. Capturing the diversity of wild Malus orientalis from Georgia, Armenia, Russia, and Turkey. J. Amer. Soc. Hort. Sci. 134:453-459.

Volk, G.M., C.M. Richards, A.A. Reilley, A.D. Henk, P.L. Forsline, and H.S. Aldwinckle. 2005. Ex situ conservation of vegetatively propagated species: Development of a seed-based core collection for Malus sieversii. J. Amer. Soc. Hort. Sci. 130:203-210.

Wang, J.-C., J. Hu, N.-N. Liu, H.-M. Xu, and S. Zhang. 2006a. Investigation of combining plant genotypic values and molecular marker information for constructing core subsets. J. Integr. Plant Biol. 48:1371-1378.

Wang, J.C., J. Hu, H.M. Xu, and S. Zhang. 2007. A strategy on constructing core collections by least distance stepwise sampling. Theor. Appl. Genet. 115:1-8.

Wang, L., Y. Guan, R. Guan, Y. Li, Y. Ma, Z. Dong, X. Liu, H. Zhang, Y. Zhang, Z. Liu, R. Chang, H. Xu, L. Li, F. Lin, W. Luan, Z. Yan, X. Ning, L. Zhu, Y. Cui, R. Piao, Y. Liu, P. Chen, and L. Qiu. 2006b. Establishment of Chinese soybean (Glycine max) core collections with agronomic traits and SSR markers. Euphytica 151:215-223. Young, W.J. 1914. A study of variation in the apple. Amer. Nat. 48:595-634.

Yue, C., R.K. Gallardo, J. Luby, J. McFerson, L. Liu, and A. Iezzoni. 2012. Technical and socio-economic challenges to setting and implementing priorities in North American rosaceous fruit breeding programs. HortScience 47:1320-1327. 
Supplemental Table 1. Apple accessions in the original Malus core collection, which was designed to be representative of the Plant Genetic Resources Unit grafted apple collection in the 1990s. ${ }^{\mathrm{z}}$

\begin{tabular}{|c|c|c|c|c|c|c|c|}
\hline Row (no.) & Genus & Species & PI no. & $\begin{array}{l}\text { Included } \\
\text { in analyses }\end{array}$ & Ploidy & Cultivar & Year \\
\hline 1 & Malus & angustifolia & 589727 & $\mathrm{x}$ & $2 x$ & & \\
\hline 2 & Malus & angustifolia & 589763 & $\mathrm{x}$ & $3 x$ & & \\
\hline 4 & Malus & $\times$ asiatica & 594099 & $\mathrm{x}$ & $2 \mathrm{x}$ & GMAL 1879.01 & \\
\hline 5 & Malus & $\times$ asiatica & 594107 & $\mathrm{x}$ & $2 \mathrm{x}$ & GMAL 3226.01 & \\
\hline 7 & Malus & baccata & 286599 & $\mathrm{x}$ & $2 \mathrm{x}$ & & \\
\hline 8 & Malus & baccata & 322713 & $\mathrm{x}$ & $2 \mathrm{x}$ & Mandshurica 2330 & \\
\hline 9 & Malus & baccata & 437055 & $\mathrm{x}$ & $2 \mathrm{x}$ & Flexilis & \\
\hline 10 & Malus & baccata & 588960 & $\mathrm{x}$ & $2 \mathrm{x}$ & Rockii & \\
\hline 11 & Malus & baccata & 589838 & $\mathrm{x}$ & $2 \mathrm{x}$ & Hansen's \#2 & \\
\hline 12 & Malus & baccata & 594110 & $\mathrm{x}$ & $2 \mathrm{x}$ & Jackii & \\
\hline 17 & Malus & domestica & 107196 & $\mathrm{x}$ & $2 \mathrm{x}$ & Antonovka 1.5 pounds & 1888 \\
\hline 18 & Malus & domestica & 123989 & $\mathrm{x}$ & $2 \mathrm{x}$ & Emilia & 1915 \\
\hline 19 & Malus & domestica & 188517 & $\mathrm{x}$ & $2 \mathrm{x}$ & Koningszuur & \\
\hline 20 & Malus & domestica & 246464 & $\mathrm{x}$ & $2 \mathrm{x}$ & James Grieve (Red Rosamund strain) & 1893 \\
\hline 21 & Malus & domestica & 280400 & $\mathrm{x}$ & $2 \mathrm{x}$ & Anna & 1959 \\
\hline 22 & Malus & domestica & 280401 & $\mathrm{x}$ & $2 \mathrm{x}$ & Ein Shemer & 1963 \\
\hline 23 & Malus & domestica & 383515 & $\mathrm{x}$ & $2 \mathrm{x}$ & Poeltsamaa Winter Apple & \\
\hline 24 & Malus & domestica & 392303 & $\mathrm{x}$ & $2 \mathrm{x}$ & Gala & 1934 \\
\hline 25 & Malus & domestica & 588747 & $\mathrm{x}$ & $2 \mathrm{x}$ & Florina & 1977 \\
\hline 26 & Malus & domestica & 588772 & $\mathrm{x}$ & $2 \mathrm{x}$ & Monroe & 1910 \\
\hline 27 & Malus & domestica & 588778 & $\mathrm{x}$ & $2 \mathrm{x}$ & Virginiagold & 1944 \\
\hline 35 & Malus & domestica & 588844 & $\mathrm{x}$ & $2 \mathrm{x}$ & Fuji Red Sport Type 2 & \\
\hline 36 & Malus & domestica & 588848 & $\mathrm{x}$ & $2 \mathrm{x}$ & Cortland & 1898 \\
\hline 37 & Malus & domestica & 588849 & $\mathrm{x}$ & $2 \mathrm{x}$ & Russian & 1613 \\
\hline 38 & Malus & domestica & 588850 & $\mathrm{x}$ & $2 \mathrm{x}$ & Rome Beauty Law & 1848 \\
\hline 39 & Malus & domestica & 588853 & $\mathrm{x}$ & $2 \mathrm{x}$ & Cox's Orange Pippin & 1825 \\
\hline 40 & Malus & domestica & 588859 & $\mathrm{x}$ & $2 \mathrm{x}$ & Yellow Transparent & 1850 \\
\hline 41 & Malus & domestica & 588872 & $\mathrm{x}$ & $2 \mathrm{x}$ & Northern Spy & 1800 \\
\hline 42 & Malus & domestica & 588880 & $\mathrm{x}$ & $2 \mathrm{x}$ & Granny Smith & 1868 \\
\hline 43 & Malus & domestica & 588943 & $\mathrm{x}$ & $2 \mathrm{x}$ & Liberty & 1867 \\
\hline 44 & Malus & domestica & 588955 & $\mathrm{x}$ & $2 \mathrm{x}$ & Sweet Delicious & 1911 \\
\hline 45 & Malus & domestica & 588981 & $\mathrm{x}$ & $2 \mathrm{x}$ & Mollie's Delicious & 1948 \\
\hline 46 & Malus & domestica & 588995 & $\mathrm{x}$ & $2 \mathrm{x}$ & Antonovka Kamenichka & 1889 \\
\hline 47 & Malus & domestica & 588998 & $\mathrm{x}$ & $2 \mathrm{x}$ & Marshall McIntosh & 1967 \\
\hline 48 & Malus & domestica & 589006 & $\mathrm{x}$ & $2 \mathrm{x}$ & Spokane Beauty & 1859 \\
\hline 49 & Malus & domestica & 589053 & $\mathrm{x}$ & $2 \mathrm{x}$ & Lady & 1628 \\
\hline 50 & Malus & domestica & 589122 & $\mathrm{x}$ & $2 x / 4 x$ & Kimball McIntosh 2-4-4-4 & 1948 \\
\hline 51 & Malus & domestica & 589181 & $\mathrm{x}$ & $2 \mathrm{x}$ & Prima & 1963 \\
\hline 52 & Malus & domestica & 589255 & $\mathrm{x}$ & $2 \mathrm{x}$ & Redspur Delicious & 1954 \\
\hline 53 & Malus & domestica & 589312 & $\mathrm{x}$ & $2 \mathrm{x}$ & Russian sdlg. & \\
\hline 54 & Malus & domestica & 589434 & $\mathrm{x}$ & $2 \mathrm{x}$ & Viking & 1969 \\
\hline 55 & Malus & domestica & 589441 & $\mathrm{x}$ & $2 \mathrm{x}$ & Ingol & \\
\hline
\end{tabular}


Supplemental Table 1. Continued.

\begin{tabular}{|c|c|c|c|c|c|c|c|}
\hline Row (no.) & Genus & Species & PI no. & $\begin{array}{c}\text { Included } \\
\text { in analyses }\end{array}$ & Ploidy & Cultivar & Year \\
\hline 56 & Malus & domestica & 589469 & $\mathrm{x}$ & $2 x$ & Haralson & $\overline{1913}$ \\
\hline 57 & Malus & domestica & 589478 & $\mathrm{x}$ & $2 \mathrm{x}$ & Novosibirski Sweet & \\
\hline 59 & Malus & domestica & 589490 & $\mathrm{x}$ & $2 \mathrm{x}$ & Trent & 1979 \\
\hline 60 & Malus & domestica & 589491 & $\mathrm{x}$ & $2 \mathrm{x}$ & Korichnoe Polosatoje & \\
\hline 61 & Malus & domestica & 589520 & $\mathrm{x}$ & $3 x$ & Rhode Island Greening & 1650 \\
\hline 63 & Malus & domestica & 589645 & $\mathrm{x}$ & $2 \mathrm{x}$ & Winter Majetin & 1820 \\
\hline 64 & Malus & domestica & 589648 & $\mathrm{x}$ & $2 \mathrm{x}$ & Rosemary Russet & 1831 \\
\hline 65 & Malus & domestica & 589726 & $\mathrm{x}$ & $2 \mathrm{x}$ & Britegold & 1980 \\
\hline 66 & Malus & domestica & 589841 & $\mathrm{x}$ & $2 \mathrm{x}$ & Delicious & 1879 \\
\hline 67 & Malus & domestica & 589845 & $\mathrm{x}$ & $4 \mathrm{x}$ & Smith Jonathan & 1950 \\
\hline 68 & Malus & domestica & 589894 & $\mathrm{x}$ & $2 \mathrm{x}$ & Keepsake & 1936 \\
\hline 73 & Malus & domestica & 590179 & $\mathrm{x}$ & $2 \mathrm{x}$ & E. 8 & 1944 \\
\hline 74 & Malus & domestica & 590183 & $\mathrm{x}$ & $2 \mathrm{x}$ & Dayton & 1976 \\
\hline 75 & Malus & domestica & 590184 & $\mathrm{x}$ & $2 \mathrm{x}$ & Golden Delicious & 1890 \\
\hline 76 & Malus & domestica & 590185 & $\mathrm{x}$ & $2 \mathrm{x}$ & Jonathan & 1826 \\
\hline 77 & Malus & domestica & 590186 & $\mathrm{x}$ & $2 \mathrm{x}$ & Wijcik McIntosh & 1969 \\
\hline 78 & Malus & domestica & 594108 & $\mathrm{x}$ & $2 \mathrm{x}$ & Medaille d'Or & 1865 \\
\hline 79 & Malus & domestica & 594111 & $\mathrm{x}$ & $2 \mathrm{x}$ & Redfree & \\
\hline 80 & Malus & florentina & 588868 & $\mathrm{x}$ & $2 \mathrm{x}$ & & \\
\hline 81 & Malus & florentina & 589385 & $\mathrm{x}$ & $2 \mathrm{x}$ & Skopje P2 & \\
\hline 82 & Malus & floribunda & 589827 & $\mathrm{x}$ & $2 \mathrm{x}$ & 821 & \\
\hline 83 & Malus & fusca & 589933 & $\mathrm{x}$ & $2 \mathrm{x}$ & & \\
\hline 91 & Malus & honanensis & 594113 & $\mathrm{x}$ & & & \\
\hline 92 & Malus & hupehensis & 589522 & $\mathrm{x}$ & $3 x$ & & \\
\hline 93 & Malus & Hybrid & 437057 & $\mathrm{x}$ & $2 \mathrm{x}$ & Roberts Crab & \\
\hline 94 & Malus & Hybrid & 588804 & $\mathrm{x}$ & $2 \mathrm{x}$ & Kansas K14 & \\
\hline 95 & Malus & Hybrid & 588824 & $\mathrm{x}$ & $2 \mathrm{x}$ & Almey & \\
\hline 96 & Malus & Hybrid & 588866 & $\mathrm{x}$ & $2 \mathrm{x}$ & Kerr & \\
\hline 97 & Malus & Hybrid & 588870 & $\mathrm{x}$ & $2 \mathrm{x}$ & Dolgo & \\
\hline 98 & Malus & Hybrid & 588883 & $\mathrm{x}$ & $2 \mathrm{x}$ & Demir & \\
\hline 99 & Malus & Hybrid & 588992 & $\mathrm{x}$ & $2 \mathrm{x}$ & White Angel & \\
\hline 100 & Malus & Hybrid & 589570 & $\mathrm{x}$ & $2 x$ & E36-7 & \\
\hline 101 & Malus & Hybrid & 589572 & $\mathrm{x}$ & $2 \mathrm{x}$ & E14-32 & \\
\hline 102 & Malus & Hybrid & 589775 & $\mathrm{x}$ & $2 \mathrm{x}$ & PRI 2382-1 & \\
\hline 103 & Malus & Hybrid & 589776 & $\mathrm{x}$ & $2 \mathrm{x}$ & PRI 1316-1 & \\
\hline 104 & Malus & Hybrid & 589777 & $\mathrm{x}$ & $2 \mathrm{x}$ & PRI 1918-1 & \\
\hline 105 & Malus & Hybrid & 589780 & $\mathrm{x}$ & $2 \mathrm{x}$ & PRI 384-1 & \\
\hline 106 & Malus & Hybrid & 589785 & $\mathrm{x}$ & $2 \mathrm{x}$ & PRI 1346-2 & \\
\hline 107 & Malus & Hybrid & 589786 & $\mathrm{x}$ & $2 \mathrm{x}$ & PRI 77-1 & \\
\hline 108 & Malus & Hybrid & 589789 & $\mathrm{x}$ & $2 \mathrm{x}$ & PRI 1744-1 & \\
\hline 109 & Malus & Hybrid & 589790 & $\mathrm{x}$ & $2 x$ & PRI 1484-1 & \\
\hline 110 & Malus & Hybrid & 589791 & $\mathrm{x}$ & $2 \mathrm{x}$ & PRI 1279-9 & \\
\hline 111 & Malus & Hybrid & 589792 & $\mathrm{x}$ & $2 \mathrm{x}$ & PRI 1850-4 & \\
\hline
\end{tabular}

Continued next page 
Supplemental Table 1. Continued.

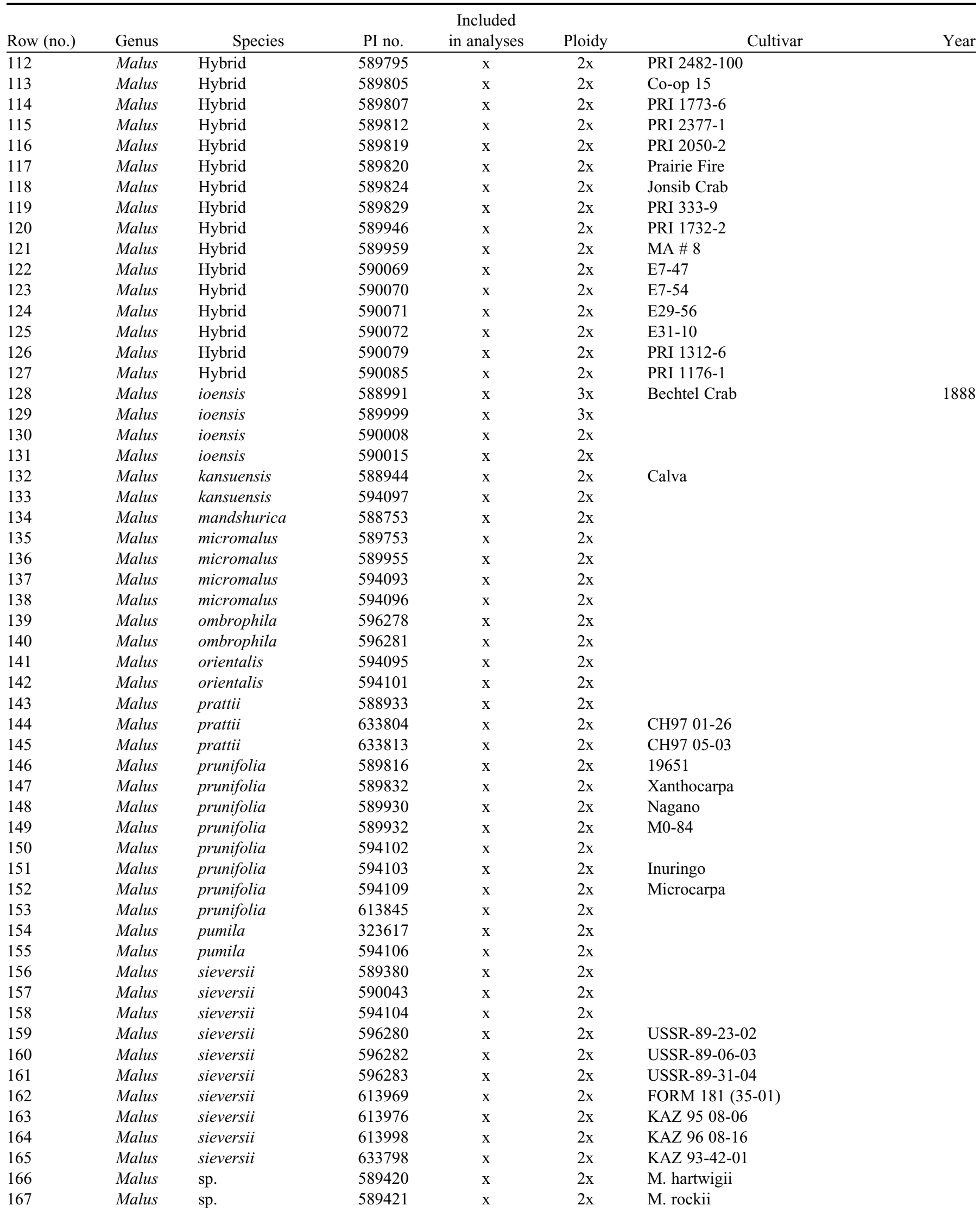


Supplemental Table 1. Continued.

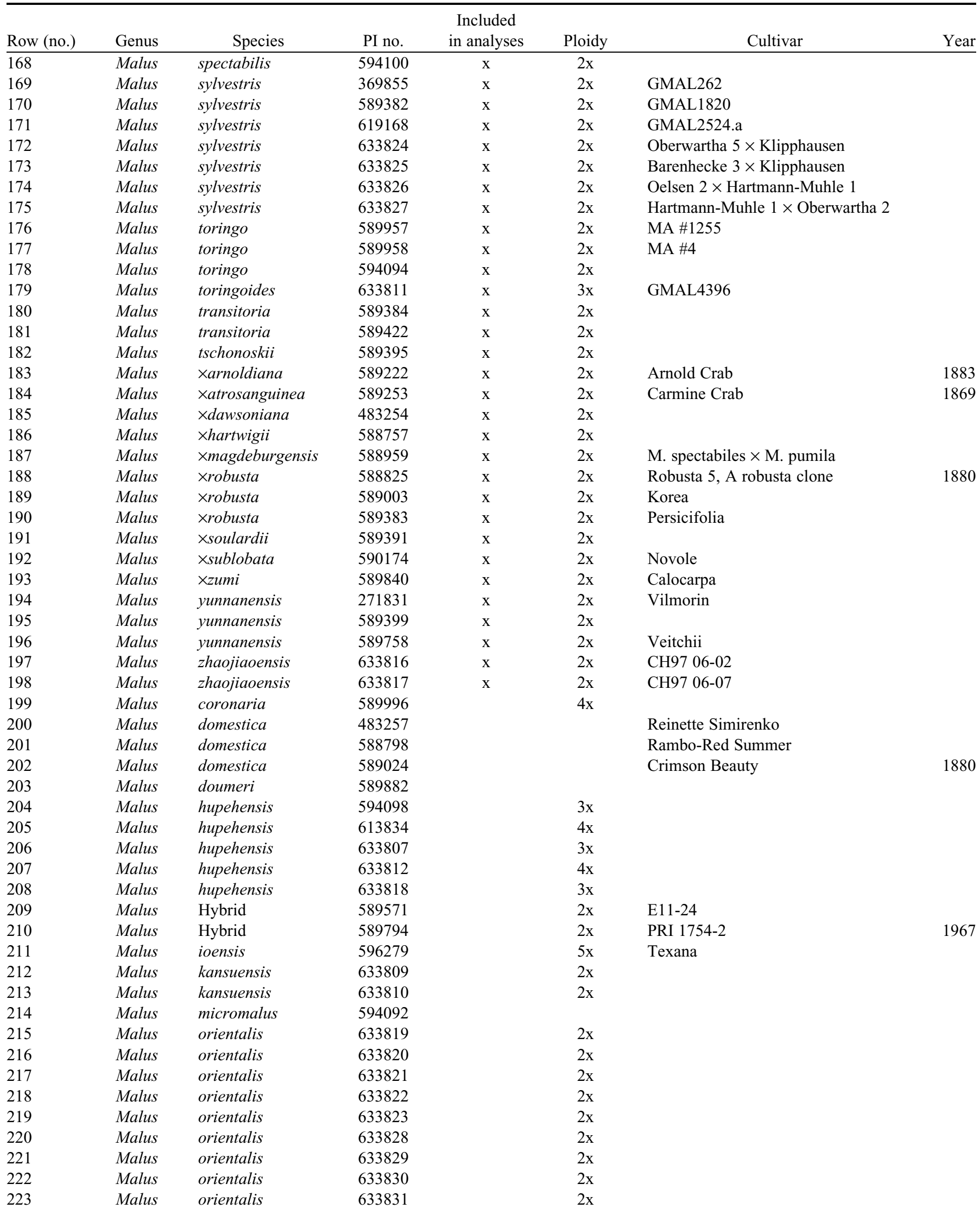

Continued next page 
Supplemental Table 1. Continued.

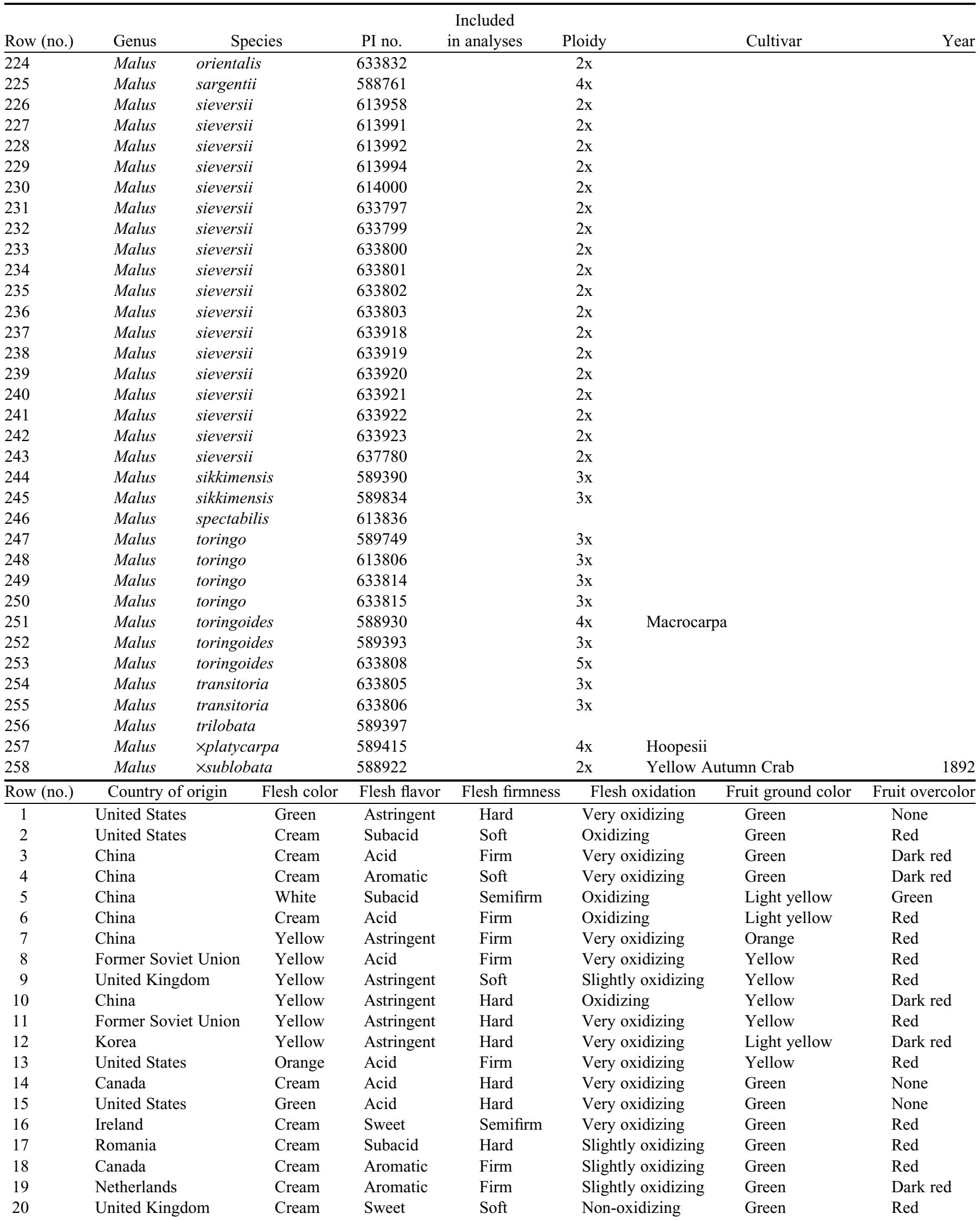


Supplemental Table 1. Continued.

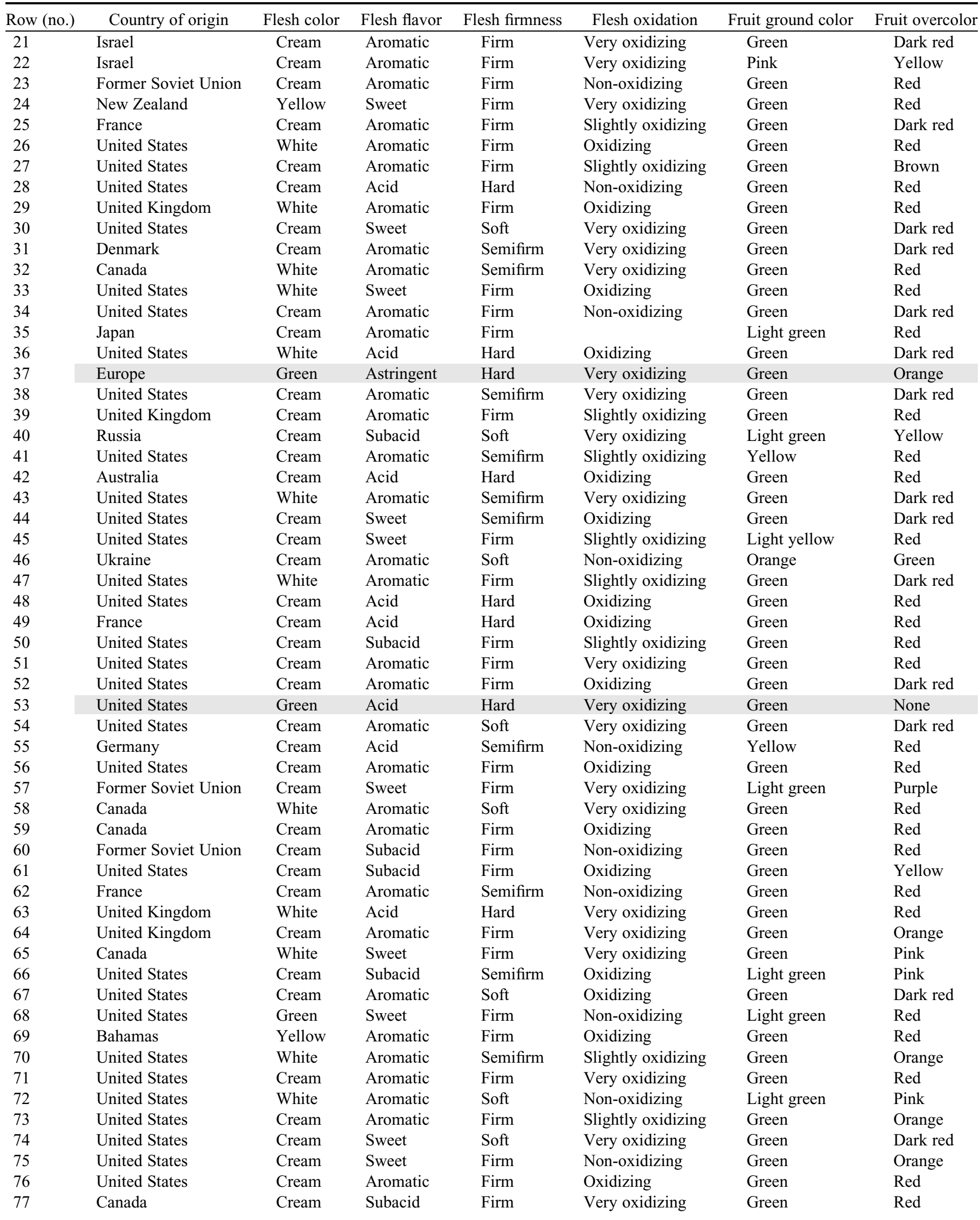


Supplemental Table 1. Continued.

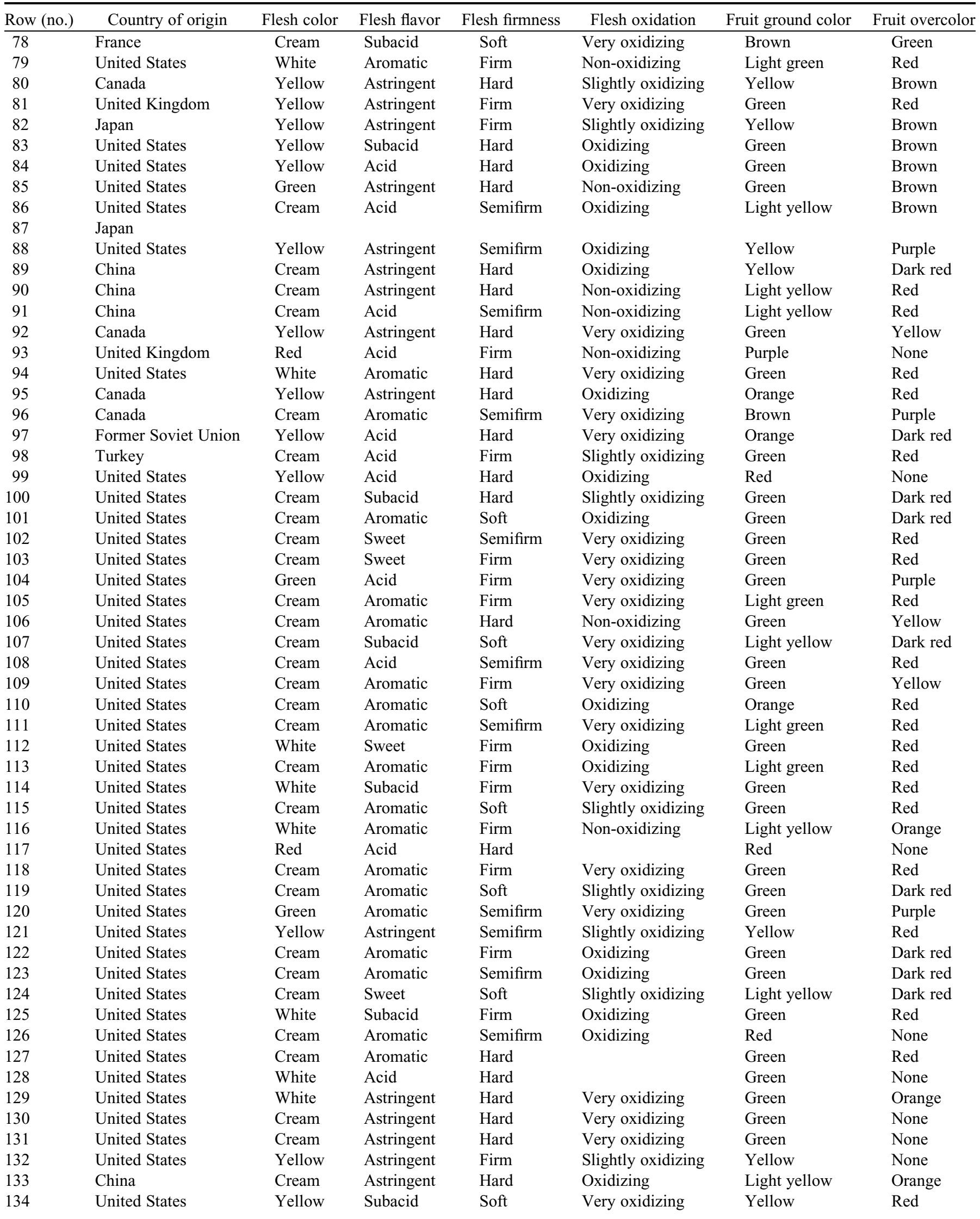


Supplemental Table 1. Continued.

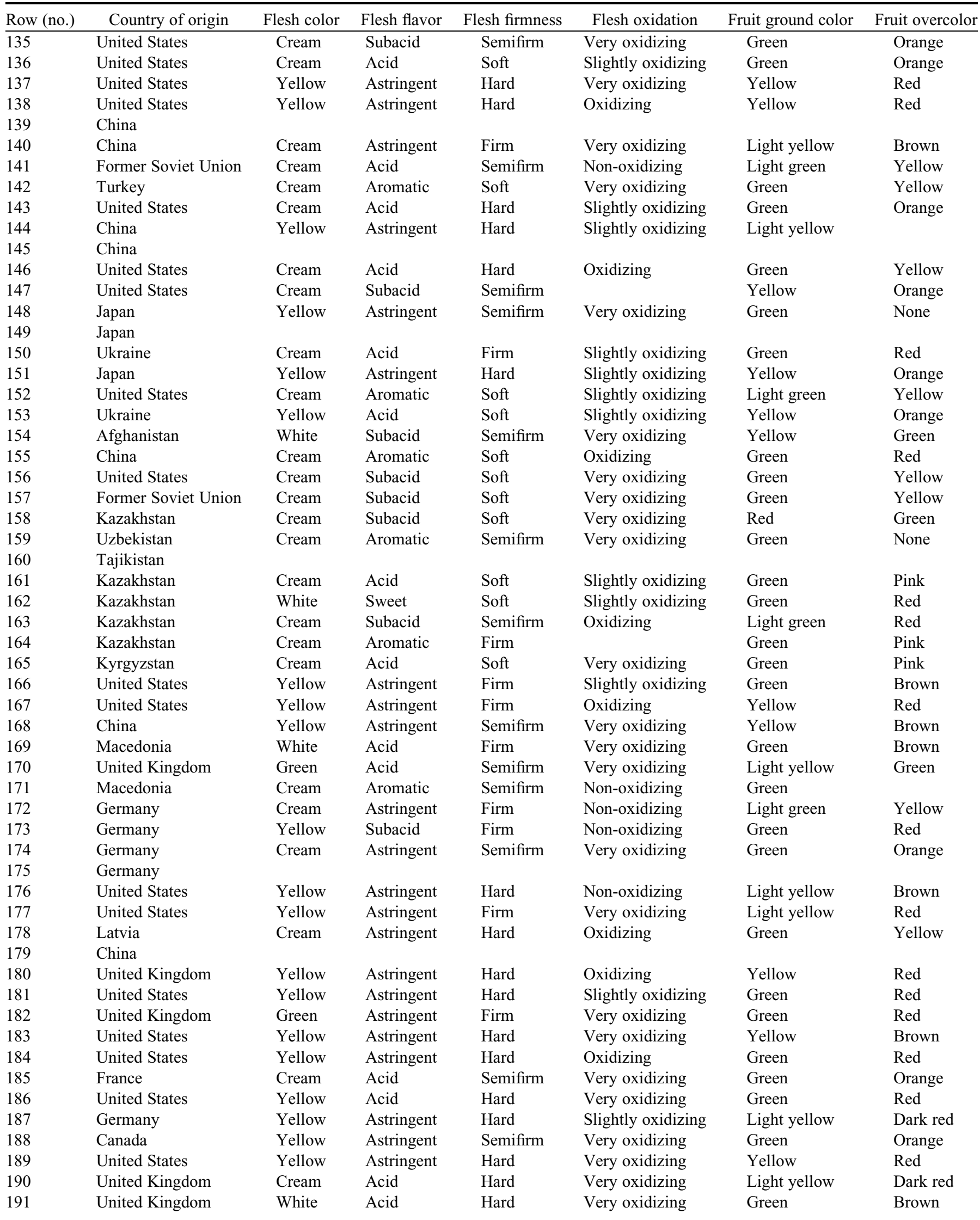


Supplemental Table 1. Continued.

\begin{tabular}{|c|c|c|c|c|c|c|c|}
\hline Row (no.) & Country of origin & Flesh color & Flesh flavor & Flesh firmness & Flesh oxidation & Fruit ground color & Fruit overcolor \\
\hline 192 & United States & Yellow & Astringent & Firm & Oxidizing & Red & None \\
\hline 193 & United States & Cream & Astringent & Firm & Slightly oxidizing & Red & None \\
\hline 194 & China & Green & Acid & Hard & Very oxidizing & Green & Brown \\
\hline 196 & China & Yellow & Astringent & Hard & Very oxidizing & Yellow & Red \\
\hline 197 & China & Yellow & Acid & Semifirm & Very oxidizing & Pink & Dark red \\
\hline 198 & China & & & & & & \\
\hline 200 & Former Soviet Union & Cream & Subacid & Firm & Slightly oxidizing & Green & Orange \\
\hline 201 & United States & Cream & Aromatic & Semifirm & Oxidizing & Green & Red \\
\hline 202 & United States & Cream & Sweet & Soft & Non-oxidizing & Light yellow & \\
\hline 203 & Taiwan & & & & & & \\
\hline 204 & China & Yellow & Astringent & Hard & Very oxidizing & Light yellow & Red \\
\hline 205 & China & Yellow & Astringent & Semifirm & Very oxidizing & Orange & Pink \\
\hline 210 & United States & Cream & Aromatic & Semifirm & Slightly oxidizing & Light yellow & Red \\
\hline 211 & United States & Green & Astringent & Hard & Very oxidizing & Green & Brown \\
\hline 212 & China & Cream & Astringent & Hard & Non-oxidizing & Pink & Brown \\
\hline 213 & China & & & & & & \\
\hline 214 & United States & Yellow & Acid & Hard & Oxidizing & Yellow & Orange \\
\hline 215 & Former Soviet Union & Cream & Astringent & Semifirm & Very oxidizing & Light green & Yellow \\
\hline 216 & Former Soviet Union & White & Astringent & Firm & Non-oxidizing & Light green & Brown \\
\hline 217 & Former Soviet Union & Cream & Astringent & Firm & Very oxidizing & Green & Yellow \\
\hline 218 & Former Soviet Union & White & Astringent & Semifirm & Non-oxidizing & Green & Orange \\
\hline 219 & Former Soviet Union & & & & & & \\
\hline 220 & Turkey & & & & & & \\
\hline 228 & Kazakhstan & Cream & Acid & Soft & Oxidizing & Green & Yellow \\
\hline 229 & Kazakhstan & Cream & Subacid & Semifirm & Very oxidizing & Light green & Brown \\
\hline 230 & Kazakhstan & Cream & Subacid & Semifirm & Slightly oxidizing & Light green & Pink \\
\hline 231 & Kazakhstan & Cream & Subacid & Semifirm & Very oxidizing & & Red \\
\hline 232 & Kazakhstan & White & Astringent & Semifirm & Very oxidizing & Light green & Red \\
\hline 233 & Kazakhstan & Cream & Astringent & Semifirm & Very oxidizing & Green & Red \\
\hline 234 & Kazakhstan & Cream & & Firm & Oxidizing & Green & Red \\
\hline 235 & Kazakhstan & Cream & Subacid & Semifirm & Very oxidizing & Light green & Pink \\
\hline 236 & Kazakhstan & Green & Subacid & Semifirm & Very oxidizing & Green & Red \\
\hline 237 & Kazakhstan & Red & Astringent & Semifirm & Slightly oxidizing & Red & None \\
\hline 238 & Kazakhstan & Cream & Subacid & Semifirm & Very oxidizing & Light yellow & Red \\
\hline 239 & Kazakhstan & Cream & Astringent & Semifirm & Very oxidizing & Green & Red \\
\hline 240 & Kazakhstan & Cream & Sweet & Firm & Very oxidizing & Green & Red \\
\hline 241 & Kazakhstan & White & Subacid & Soft & Very oxidizing & Light green & Red \\
\hline 242 & Kazakhstan & White & Astringent & Firm & Very oxidizing & Light green & Yellow \\
\hline 243 & Kazakhstan & & & & & & \\
\hline 244 & United Kingdom & Yellow & Astringent & Hard & Very oxidizing & Green & Dark red \\
\hline 245 & United States & Yellow & Astringent & Firm & Very oxidizing & Yellow & Red \\
\hline 246 & China & & & & & & \\
\hline 247 & United States & Yellow & Astringent & Hard & Slightly oxidizing & Red & None \\
\hline 248 & United States & Cream & Astringent & Semifirm & Very oxidizing & Orange & Red \\
\hline
\end{tabular}


Supplemental Table 1. Continued.

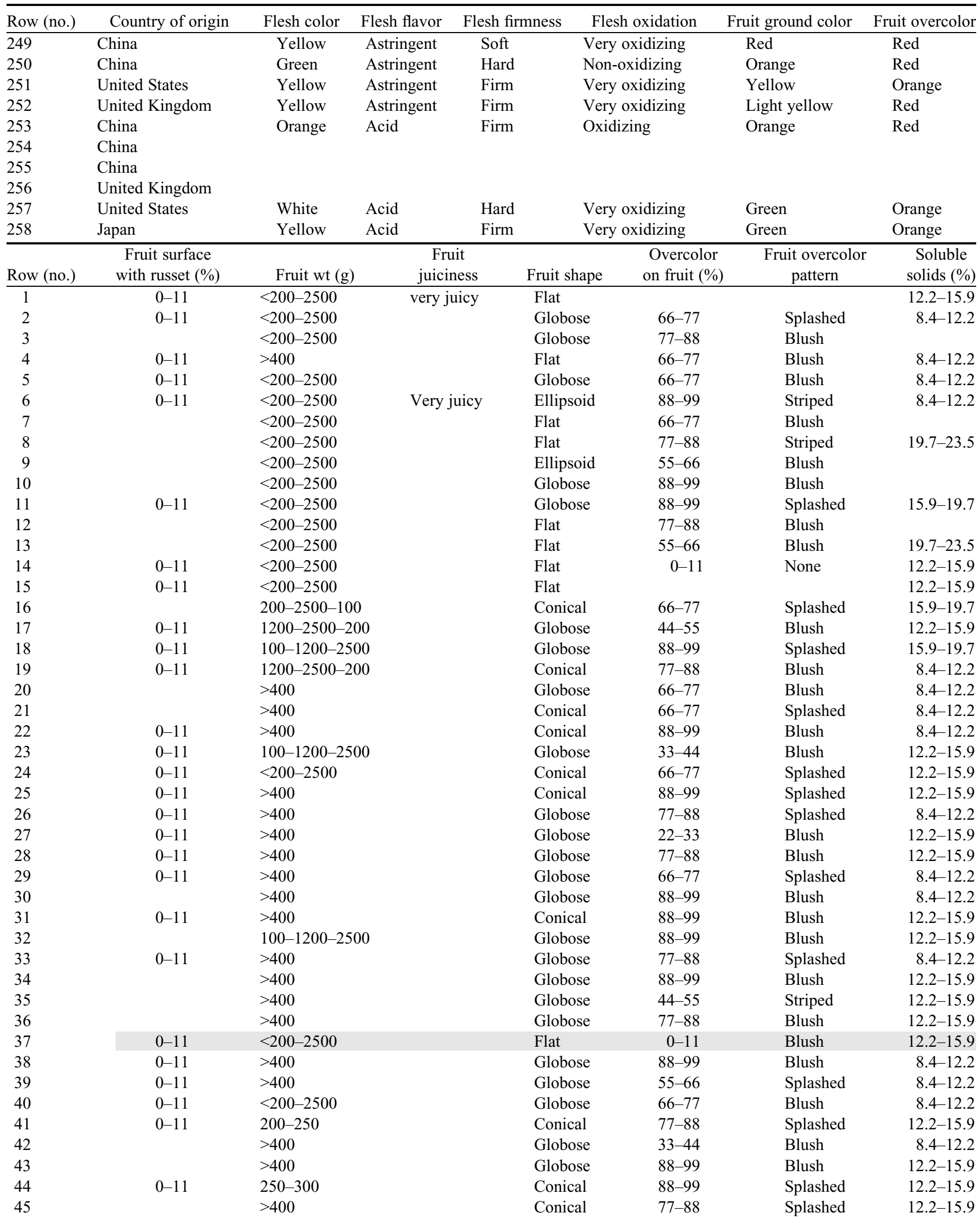


Supplemental Table 1. Continued.

\begin{tabular}{|c|c|c|c|c|c|c|c|}
\hline Row (no.) & $\begin{array}{c}\text { Fruit surface } \\
\text { with russet }(\%)\end{array}$ & Fruit wt (g) & $\begin{array}{c}\text { Fruit } \\
\text { juiciness }\end{array}$ & Fruit shape & $\begin{array}{c}\text { Overcolor } \\
\text { on fruit }(\%)\end{array}$ & $\begin{array}{c}\text { Fruit overcolor } \\
\text { pattern }\end{array}$ & $\begin{array}{c}\text { Soluble } \\
\text { solids (\%) }\end{array}$ \\
\hline 46 & $0-11$ & $>400$ & & Globose & $77-88$ & Blush & $12.2-15.9$ \\
\hline 47 & & $>400$ & & Globose & $88-99$ & Blush & $12.2-15.9$ \\
\hline 49 & $0-11$ & $<200-2500$ & & Flat & $55-66$ & Splashed & $12.2-15.9$ \\
\hline 50 & $0-11$ & $200-250$ & & Flat & $66-77$ & Blush & $12.2-15.9$ \\
\hline 53 & $0-11$ & $<200-2500$ & & Flat & & & $8.4-12.2$ \\
\hline 54 & & $>400$ & & Globose & $88-99$ & Blush & $12.2-15.9$ \\
\hline 55 & $0-11$ & $>400$ & & Globose & $66-77$ & Splashed & $12.2-15.9$ \\
\hline 56 & $0-11$ & $>400$ & & Globose & $88-99$ & Striped & $12.2-15.9$ \\
\hline 57 & $0-11$ & $<200-2500$ & & Globose & $55-66$ & Blush & $12.2-15.9$ \\
\hline 58 & & $>400$ & & Globose & $88-99$ & Blush & $12.2-15.9$ \\
\hline 62 & $11-22$ & $1200-2500-200$ & & Conical & $22-33$ & Blush & $12.2-15.9$ \\
\hline 63 & $0-11$ & $>400$ & & Globose & $44-55$ & Blush & $8.4-12.2$ \\
\hline 64 & $11-22$ & $>400$ & & Conical & $33-44$ & Blush & $12.2-15.9$ \\
\hline 65 & $0-11$ & $200-250$ & Dry & Oblong & $66-77$ & Blush & $8.4-12.2$ \\
\hline 66 & $0-11$ & $100-1200-2500$ & Medium & Oblong & $44-55$ & Striped & $8.4-12.2$ \\
\hline 67 & $0-11$ & $1200-2500-200$ & & Globose & $88-99$ & Blush & $12.2-15.9$ \\
\hline 68 & $0-11$ & $>400$ & & Globose & $77-88$ & Splashed & $12.2-15.9$ \\
\hline 69 & $0-11$ & $200-2500-100$ & & Conical & $55-66$ & Blush & $12.2-15.9$ \\
\hline 70 & $0-11$ & $>400$ & & Conical & $55-66$ & Blush & $8.4-12.2$ \\
\hline 71 & & $>400$ & & Globose & $88-99$ & Splashed & $8.4-12.2$ \\
\hline 72 & $0-11$ & $>400$ & & Globose & $55-66$ & Striped & $12.2-15.9$ \\
\hline 73 & $0-11$ & $250-300$ & & Conical & $88-99$ & Splashed & $15.9-19.7$ \\
\hline 81 & & $<200-2500$ & & Ellipsoid & $33-44$ & Blush & $27.2-31.0$ \\
\hline 82 & $11-22$ & $<200-2500$ & & Globose & $11-22$ & Blush & $23.5-27.2$ \\
\hline 83 & & $<200-2500$ & & Ellipsoid & $55-66$ & Blush & $12.2-15.9$ \\
\hline 84 & & $<200-2500$ & & Ellipsoid & $66-77$ & Blush & $15.9-19.7$ \\
\hline 85 & $0-11$ & $<200-2500$ & & Oblong & $55-66$ & Blush & $15.9-19.7$ \\
\hline 86 & & $<200-2500$ & & Oblong & $44-55$ & Blush & $15.9-19.7$ \\
\hline \multicolumn{8}{|l|}{87} \\
\hline 88 & $0-11$ & $<200-2500$ & Very juicy & Flat & $88-99$ & Blush & $19.7-23.5$ \\
\hline 89 & & $<200-2500$ & & Globose & $66-77$ & Blush & \\
\hline 90 & & $<200-2500$ & & Flat & $77-88$ & Blush & $19.7-23.5$ \\
\hline 91 & & $<200-2500$ & & Globose & $88-99$ & Blush & \\
\hline 92 & & $<200-2500$ & & Flat & $33-44$ & Blush & $19.7-23.5$ \\
\hline 93 & $0-11$ & $200-2500-100$ & & Globose & $0-11$ & & $12.2-15.9$ \\
\hline 94 & $0-11$ & $>400$ & & Globose & $55-66$ & Splashed & $8.4-12.2$ \\
\hline 95 & & $<200-2500$ & & Ellipsoid & $77-88$ & Blush & $19.7-23.5$ \\
\hline 96 & $0-11$ & $>400$ & & Flat & $77-88$ & Striped & $8.4-12.2$ \\
\hline 97 & $0-11$ & $<200-2500$ & & Globose & $77-88$ & Blush & $15.9-19.7$ \\
\hline 98 & & $200-2500-100$ & & Globose & $55-66$ & Blush & $12.2-15.9$ \\
\hline 99 & $0-11$ & $<200-2500$ & & Flat & $0-11$ & None & $19.7-23.5$ \\
\hline 100 & $0-11$ & $100-1200-2500$ & & Globose & $88-99$ & Blush & $15.9-19.7$ \\
\hline 101 & & $>400$ & & Globose & $66-77$ & Blush & $12.2-15.9$ \\
\hline
\end{tabular}


Supplemental Table 1. Continued.

\begin{tabular}{|c|c|c|c|c|c|c|c|}
\hline Row (no.) & $\begin{array}{c}\text { Fruit surface } \\
\text { with russet }(\%)\end{array}$ & Fruit wt (g) & $\begin{array}{c}\text { Fruit } \\
\text { juiciness }\end{array}$ & Fruit shape & $\begin{array}{c}\text { Overcolor } \\
\text { on fruit }(\%)\end{array}$ & $\begin{array}{c}\text { Fruit overcolor } \\
\text { pattern }\end{array}$ & $\begin{array}{c}\text { Soluble } \\
\text { solids (\%) }\end{array}$ \\
\hline 102 & $0-11$ & $>400$ & & Conical & $77-88$ & Blush & $8.4-12.2$ \\
\hline 103 & & $>400$ & & Conical & $66-77$ & Splashed & $8.4-12.2$ \\
\hline 105 & & $>400$ & & Globose & $33-44$ & Blush & $12.2-15.9$ \\
\hline 106 & $0-11$ & $>400$ & & Globose & $77-88$ & Blush & $12.2-15.9$ \\
\hline 109 & & $>400$ & & Conical & $33-44$ & Blush & $8.4-12.2$ \\
\hline 110 & & $>400$ & & Globose & $66-77$ & Blush & $12.2-15.9$ \\
\hline 111 & $0-11$ & $>400$ & & Globose & $66-77$ & Splashed & $12.2-15.9$ \\
\hline 112 & $0-11$ & $>400$ & & Conical & $66-77$ & Blush & $8.4-12.2$ \\
\hline 113 & & $>400$ & & Globose & $88-99$ & Blush & $12.2-15.9$ \\
\hline 114 & $0-11$ & $100-1200-2500$ & & Globose & $66-77$ & Blush & $12.2-15.9$ \\
\hline 119 & $0-11$ & $>400$ & & Globose & $88-99$ & Blush & $12.2-15.9$ \\
\hline 120 & & $>400$ & & Globose & $77-88$ & Splashed & $8.4-12.2$ \\
\hline 121 & $0-11$ & $<200-2500$ & & Globose & $77-88$ & Blush & $27.2-31.0$ \\
\hline 122 & $0-11$ & $>400$ & & Globose & $88-99$ & Blush & $12.2-15.9$ \\
\hline 123 & & $100-1200-2500$ & & Globose & $88-99$ & Blush & $12.2-15.9$ \\
\hline 124 & & $>400$ & & Globose & $88-99$ & Splashed & $8.4-12.2$ \\
\hline 125 & $0-11$ & $>400$ & & Globose & $77-88$ & Blush & $8.4-12.2$ \\
\hline 126 & & $>400$ & & Conical & $0-11$ & None & $12.2-15.9$ \\
\hline 127 & & $>400$ & & Globose & $88-99$ & Splashed & $8.4-12.2$ \\
\hline 128 & & & & Flat & & & \\
\hline 129 & & $<200-2500$ & & Flat & $33-44$ & Blush & $12.2-15.9$ \\
\hline 137 & & $<200-2500$ & & Flat & $66-77$ & Blush & $27.2-31.0$ \\
\hline 138 & & $<200-2500$ & & Flat & $88-99$ & Blush & \\
\hline \multicolumn{8}{|l|}{139} \\
\hline 140 & $0-11$ & $<200-2500$ & Very juicy & Ellipsoid & $77-88$ & Blush & $19.7-23.5$ \\
\hline 141 & & $<200-2500$ & & Globose & $88-99$ & Blush & $8.4-12.2$ \\
\hline 142 & & $<200-2500$ & & Globose & $66-77$ & Blush & \\
\hline 143 & $0-11$ & $<200-2500$ & & Globose & $33-44$ & Blush & \\
\hline 144 & $55-66$ & $<200-2500$ & Very juicy & Globose & $88-99$ & Blush & $19.7-23.5$ \\
\hline \multicolumn{8}{|l|}{145} \\
\hline 146 & & $<200-2500$ & & Globose & $88-99$ & Blush & $15.9-19.7$ \\
\hline 147 & & $<200-2500$ & & Globose & $33-44$ & Blush & \\
\hline 148 & & $<200-2500$ & & Globose & $0-11$ & Blush & $12.2-15.9$ \\
\hline \multicolumn{8}{|l|}{149} \\
\hline 150 & $0-11$ & $<200-2500$ & & Globose & $66-77$ & Blush & $12.2-15.9$ \\
\hline 151 & $0-11$ & $200-2500-100$ & & Globose & $11-22$ & Blush & \\
\hline 152 & $0-11$ & $<200-2500$ & & Flat & $88-99$ & Blush & \\
\hline 153 & $0-11$ & $<200-2500$ & & Globose & $44-55$ & Splashed & $15.9-19.7$ \\
\hline 154 & & $<200-2500$ & & Flat & $77-88$ & Blush & $8.4-12.2$ \\
\hline 155 & & $>400$ & & Conical & $66-77$ & Splashed & \\
\hline 156 & $0-11$ & $<200-2500$ & & Globose & $77-88$ & Blush & $8.4-12.2$ \\
\hline 157 & $0-11$ & $<200-2500$ & & Globose & $66-77$ & Blush & \\
\hline
\end{tabular}


Supplemental Table 1. Continued.

\begin{tabular}{|c|c|c|c|c|c|c|c|}
\hline Row (no.) & $\begin{array}{c}\text { Fruit surface } \\
\text { with russet }(\%)\end{array}$ & Fruit wt (g) & $\begin{array}{c}\text { Fruit } \\
\text { juiciness }\end{array}$ & Fruit shape & $\begin{array}{c}\text { Overcolor } \\
\text { on fruit }(\%)\end{array}$ & $\begin{array}{c}\text { Fruit overcolor } \\
\text { pattern }\end{array}$ & $\begin{array}{c}\text { Soluble } \\
\text { solids (\%) }\end{array}$ \\
\hline 158 & $0-11$ & $<200-2500$ & & Globose & $66-77$ & Blush & $12.2-15.9$ \\
\hline 159 & $0-11$ & $200-2500-100$ & Medium & Flat & & & $8.4-12.2$ \\
\hline 161 & $0-11$ & $<200-2500$ & Dry & Ellipsoid & $0-11$ & Blush & $8.4-12.2$ \\
\hline 162 & $0-11$ & $200-2500-100$ & Very dry & Flat & $88-99$ & Blush & $8.4-12.2$ \\
\hline 165 & $0-11$ & $<200-2500$ & Very dry & Globose & $0-11$ & Striped & $8.4-12.2$ \\
\hline 166 & & $<200-2500$ & & Globose & $88-99$ & Blush & \\
\hline 167 & & $<200-2500$ & & Flat & $88-99$ & Blush & $27.2-31.0$ \\
\hline 168 & & $<200-2500$ & & Globose & $55-66$ & Blush & $23.5-27.2$ \\
\hline 169 & & $<200-2500$ & & Flat & $0-11$ & Blush & $8.4-12.2$ \\
\hline 170 & $11-22$ & $>400$ & & Globose & $88-99$ & Blush & \\
\hline \multicolumn{8}{|l|}{175} \\
\hline 176 & $0-11$ & $<200-2500$ & Very juicy & Globose & $66-77$ & Blush & \\
\hline 177 & & $<200-2500$ & & Globose & $88-99$ & Blush & \\
\hline 178 & & $<200-2500$ & & Flat & $44-55$ & Blush & \\
\hline \multicolumn{8}{|l|}{179} \\
\hline 180 & & $<200-2500$ & & Globose & $55-66$ & Blush & \\
\hline 181 & & $<200-2500$ & & Globose & $77-88$ & Blush & \\
\hline 182 & $0-11$ & $<200-2500$ & Very juicy & Flat & $44-55$ & Blush & $23.5-27.2$ \\
\hline 183 & $0-11$ & $<200-2500$ & & Globose & $44-55$ & Blush & $27.2-31.0$ \\
\hline 184 & $0-11$ & $<200-2500$ & & Globose & $66-77$ & Blush & $19.7-23.5$ \\
\hline 185 & $0-11$ & $<200-2500$ & & Ellipsoid & $33-44$ & Blush & $8.4-12.2$ \\
\hline 193 & & $<200-2500$ & & Globose & $0-11$ & None & \\
\hline 194 & $0-11$ & $<200-2500$ & & Oblong & $88-99$ & Blush & $19.7-23.5$ \\
\hline 195 & $0-11$ & $<200-2500$ & & Globose & $33-44$ & Blush & $23.5-27.2$ \\
\hline 196 & $0-11$ & $<200-2500$ & & Flat & $66-77$ & Blush & $23.5-27.2$ \\
\hline 197 & $0-11$ & $<200-2500$ & Very juicy & Flat & $77-88$ & Blush & $23.5-27.2$ \\
\hline \multicolumn{8}{|l|}{198} \\
\hline 199 & & $<200-2500$ & & Flat & $33-44$ & Blush & $12.2-15.9$ \\
\hline 200 & & $100-1200-2500$ & & Globose & $11-22$ & Blush & $12.2-15.9$ \\
\hline 201 & & $>400$ & & Globose & $77-88$ & Splashed & $8.4-12.2$ \\
\hline 202 & $0-11$ & $100-1200-2500$ & Very dry & Flat & & Blush & $8.4-12.2$ \\
\hline \multicolumn{8}{|l|}{203} \\
\hline 204 & & $<200-2500$ & & Flat & $88-99$ & Blush & $27.2-31.0$ \\
\hline 205 & $0-11$ & $<200-2500$ & & Globose & $55-66$ & Blush & $27.2-31.0$ \\
\hline 206 & $0-11$ & $<200-2500$ & Very juicy & Flat & $88-99$ & Blush & $0.9-4.7$ \\
\hline 207 & $0-11$ & $<200-2500$ & Very juicy & Flat & $66-77$ & Blush & $27.2-31.0$ \\
\hline 208 & $0-11$ & $<200-2500$ & Medium & Flat & $33-44$ & Blush & $27.2-31.0$ \\
\hline 209 & & $>400$ & & Globose & $66-77$ & Splashed & $12.2-15.9$ \\
\hline 210 & $0-11$ & $1200-2500-200$ & Mod. Juicy & Globose & $77-88$ & Blush & $12.2-15.9$ \\
\hline 211 & $0-11$ & $<200-2500$ & Very juicy & Flat & $22-33$ & Blush & $12.2-15.9$ \\
\hline 212 & $0-11$ & $<200-2500$ & Very juicy & Oblong & $22-33$ & Blush & $23.5-27.2$ \\
\hline
\end{tabular}


Supplemental Table 1. Continued.

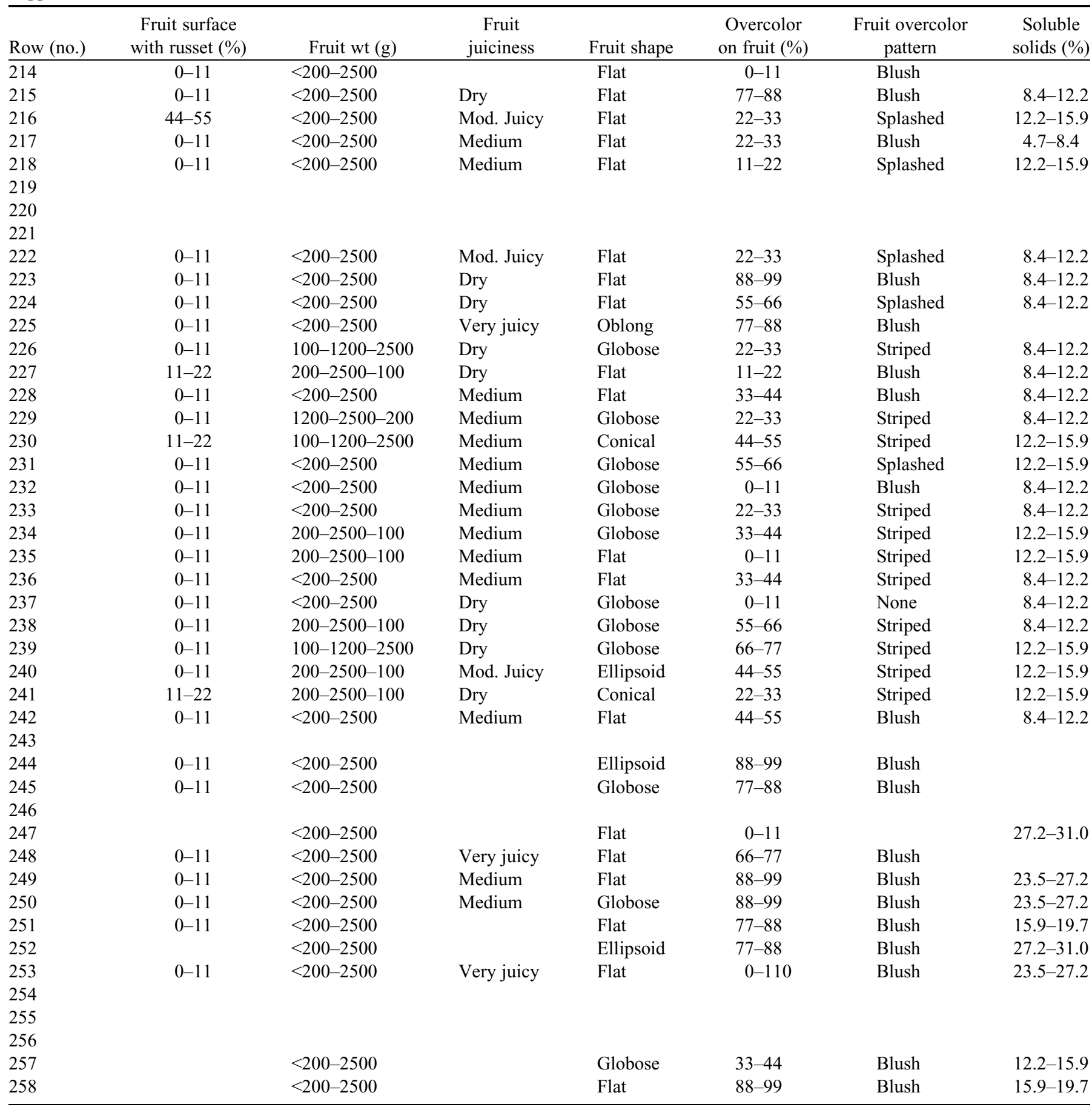

${ }^{z}$ Individuals highlighted in gray were identified as duplicates by Gross et al. (2012b). Trait data are from the Genetic Resources Information Network [GRIN (U.S. Department of Agriculture, 2012)]. 


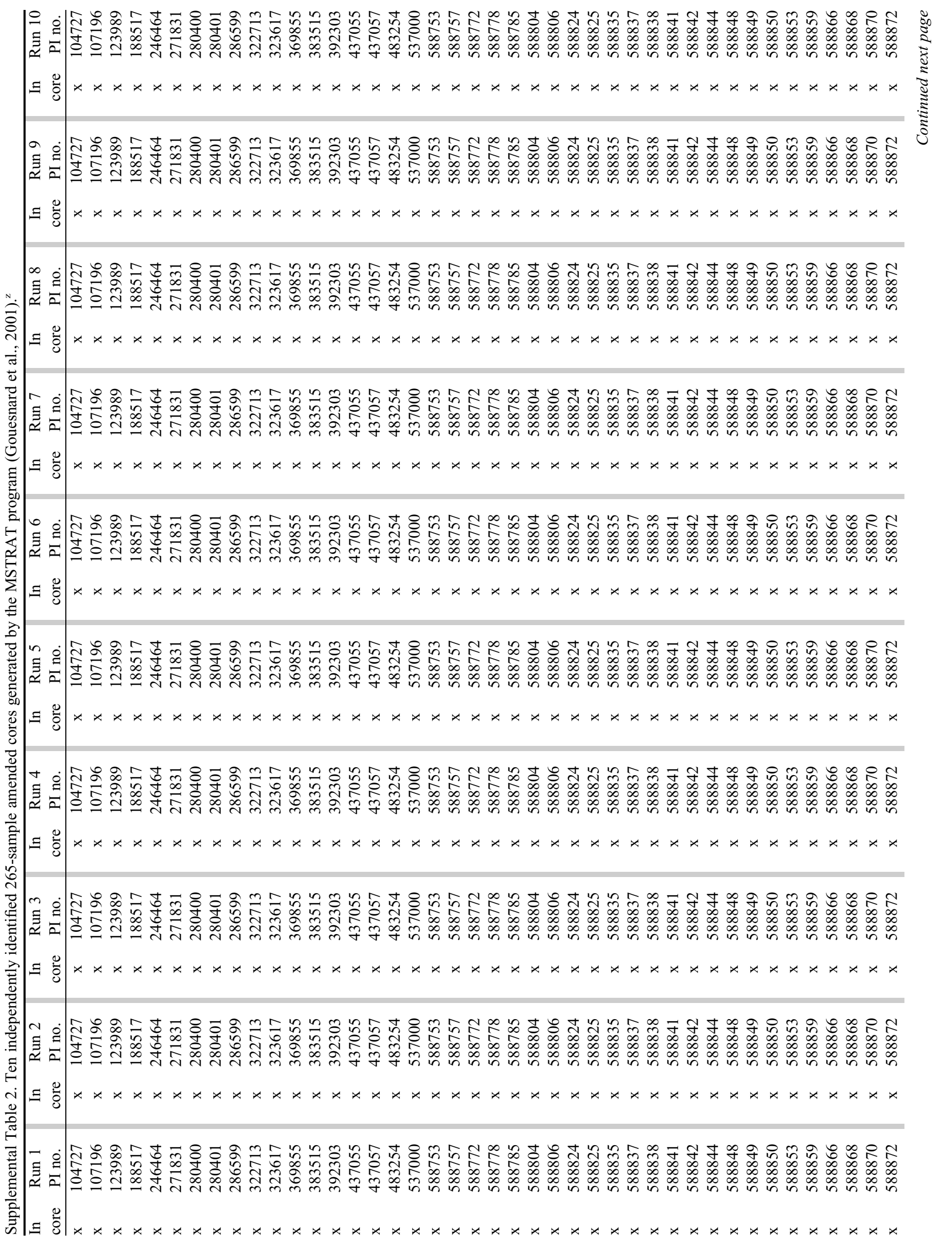




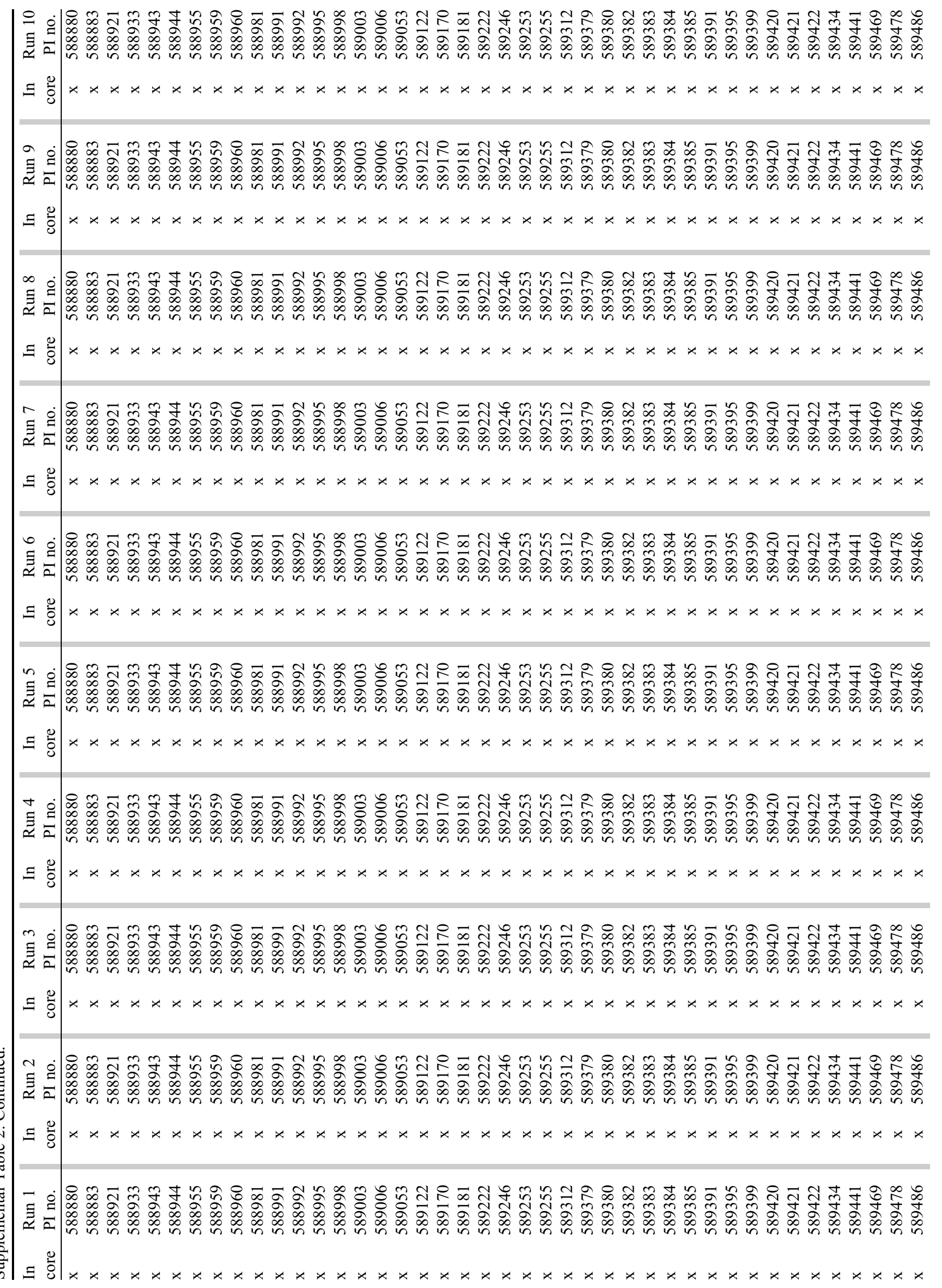




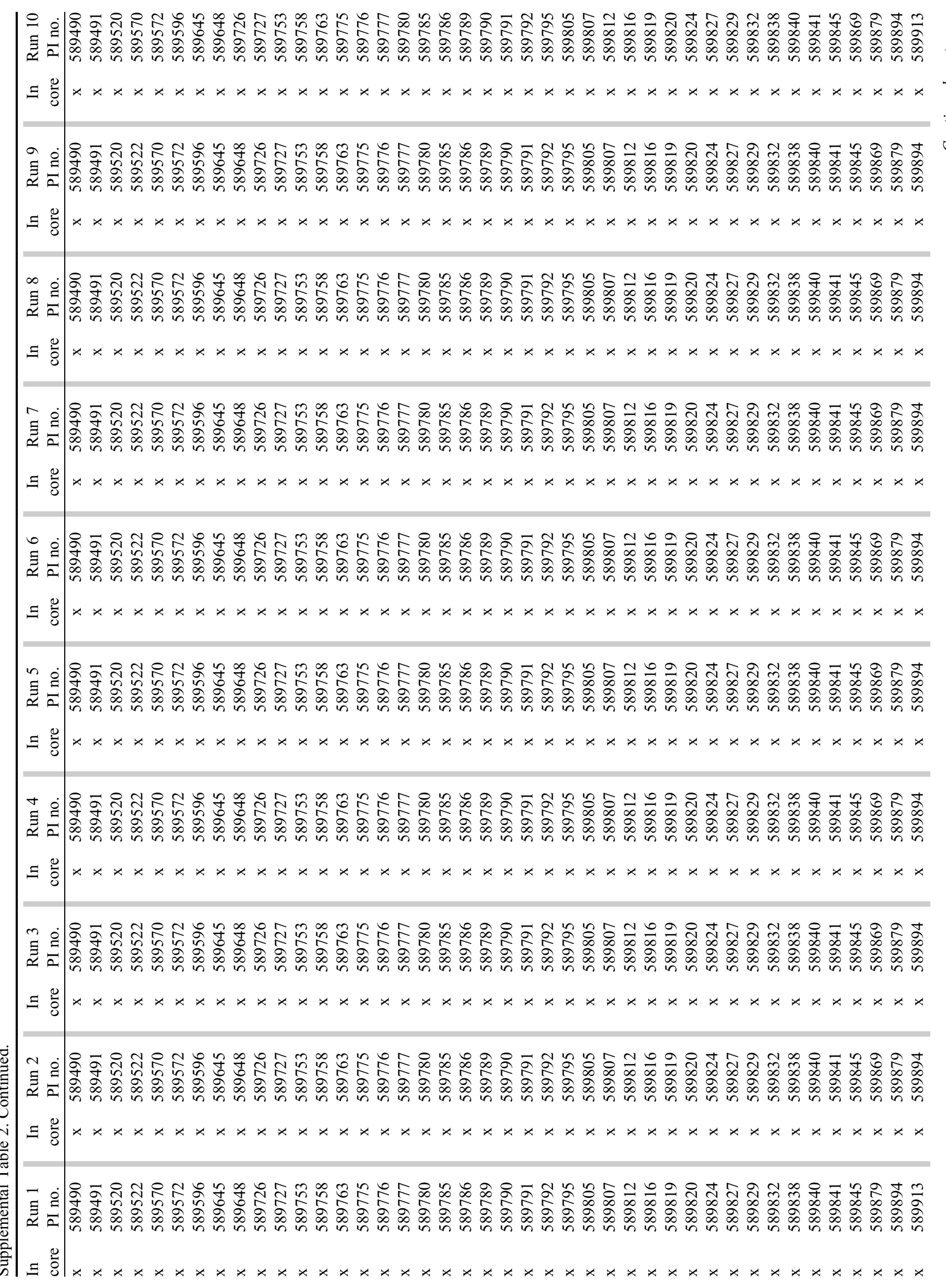




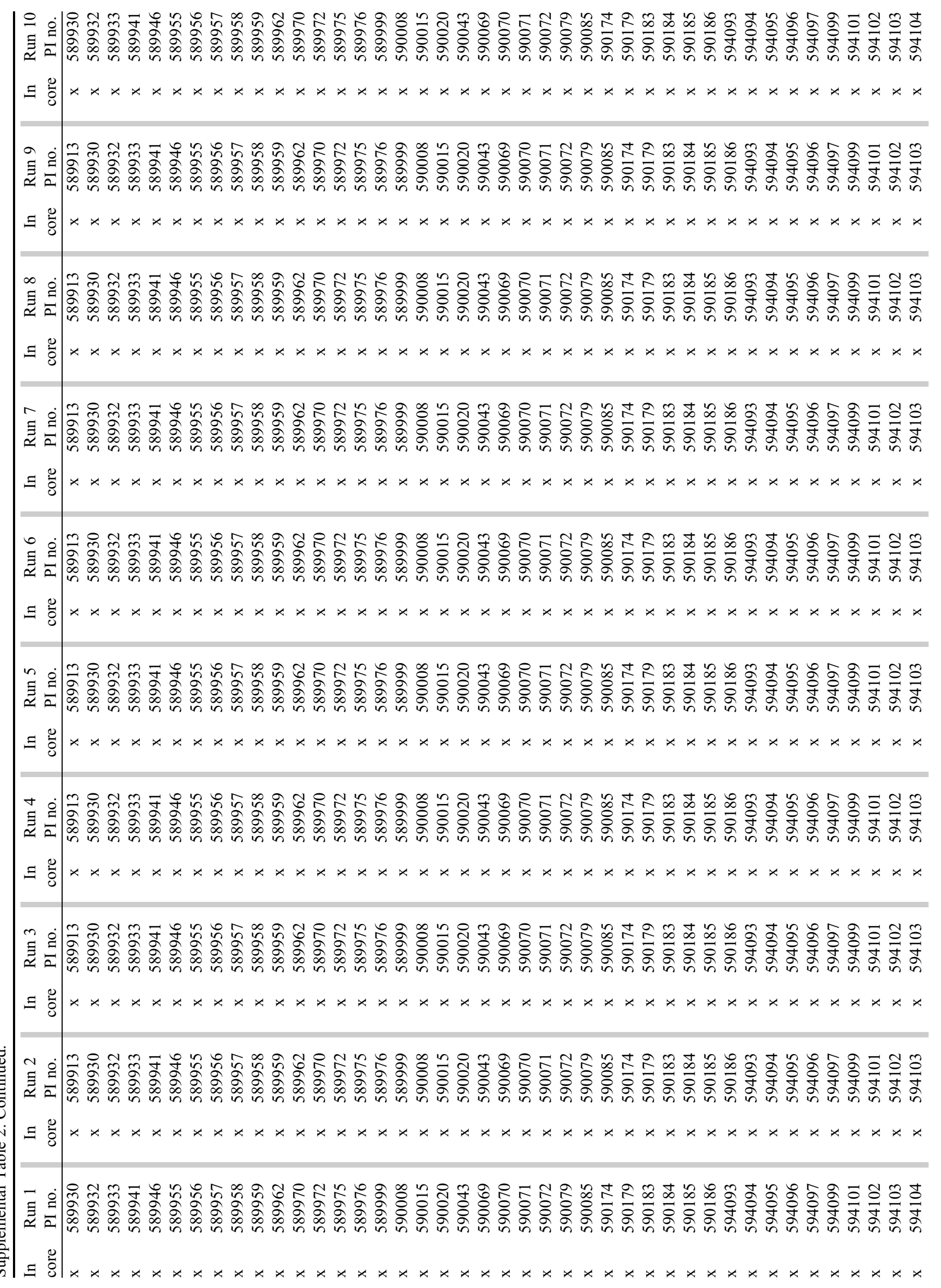




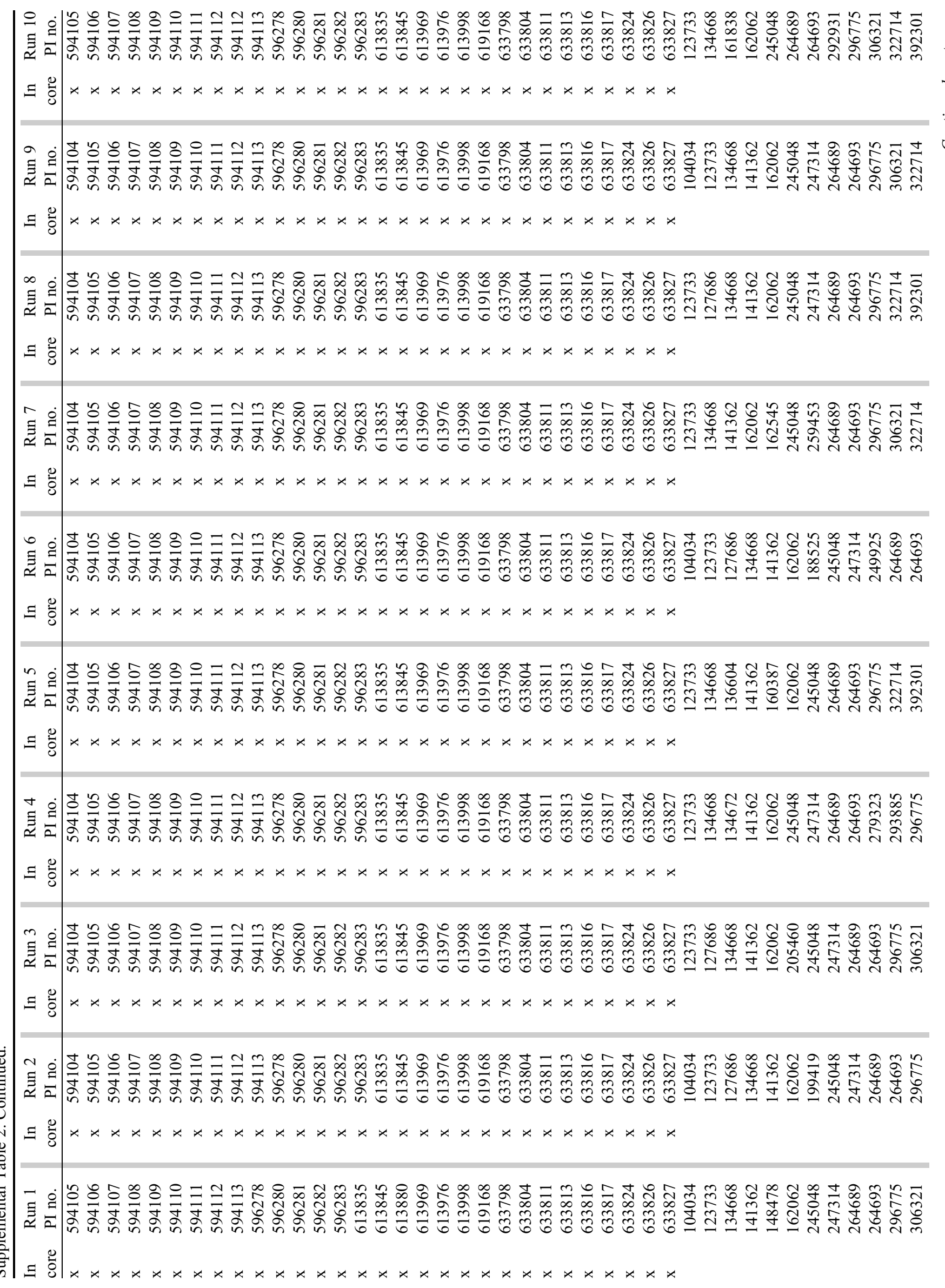




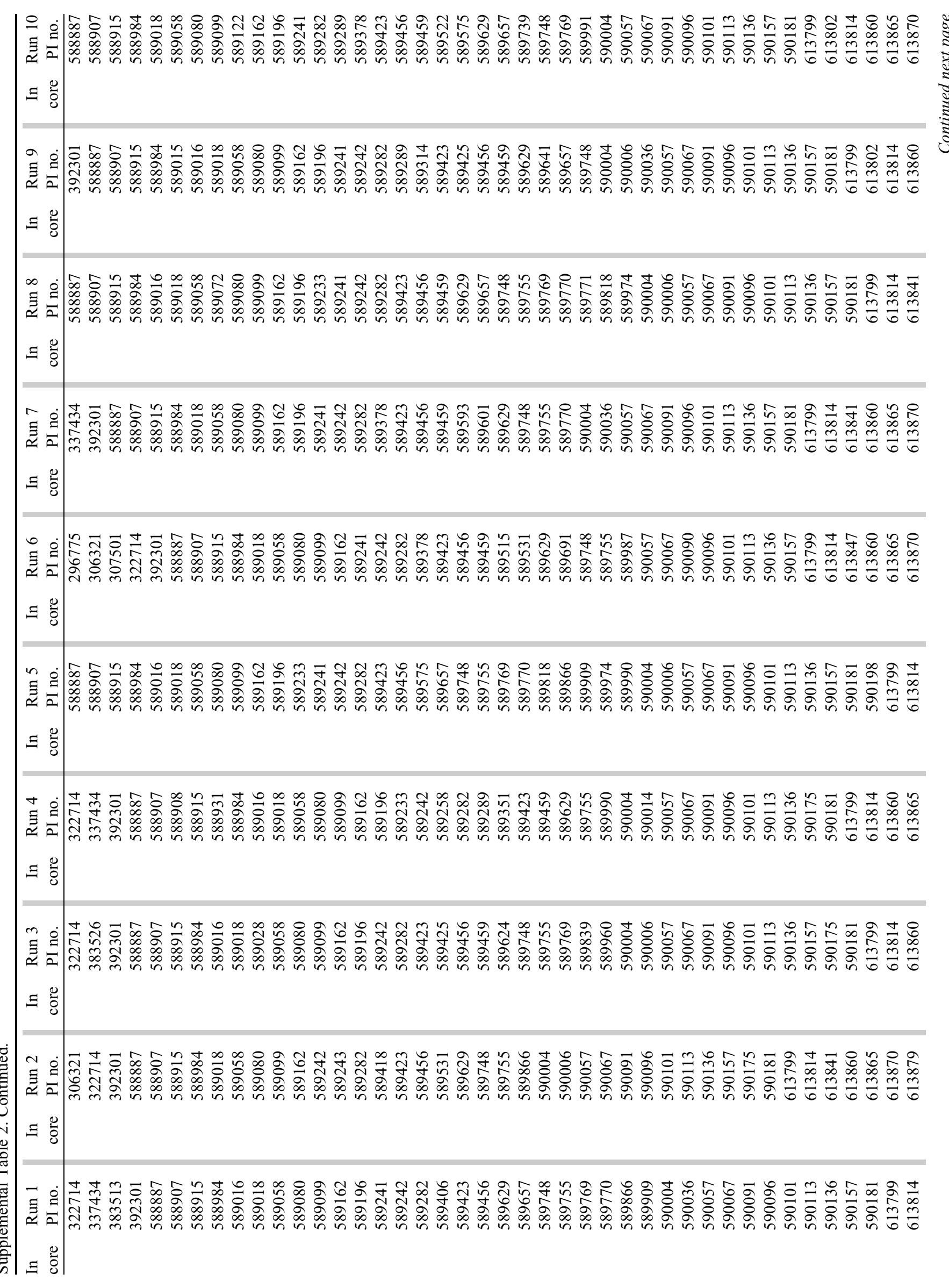



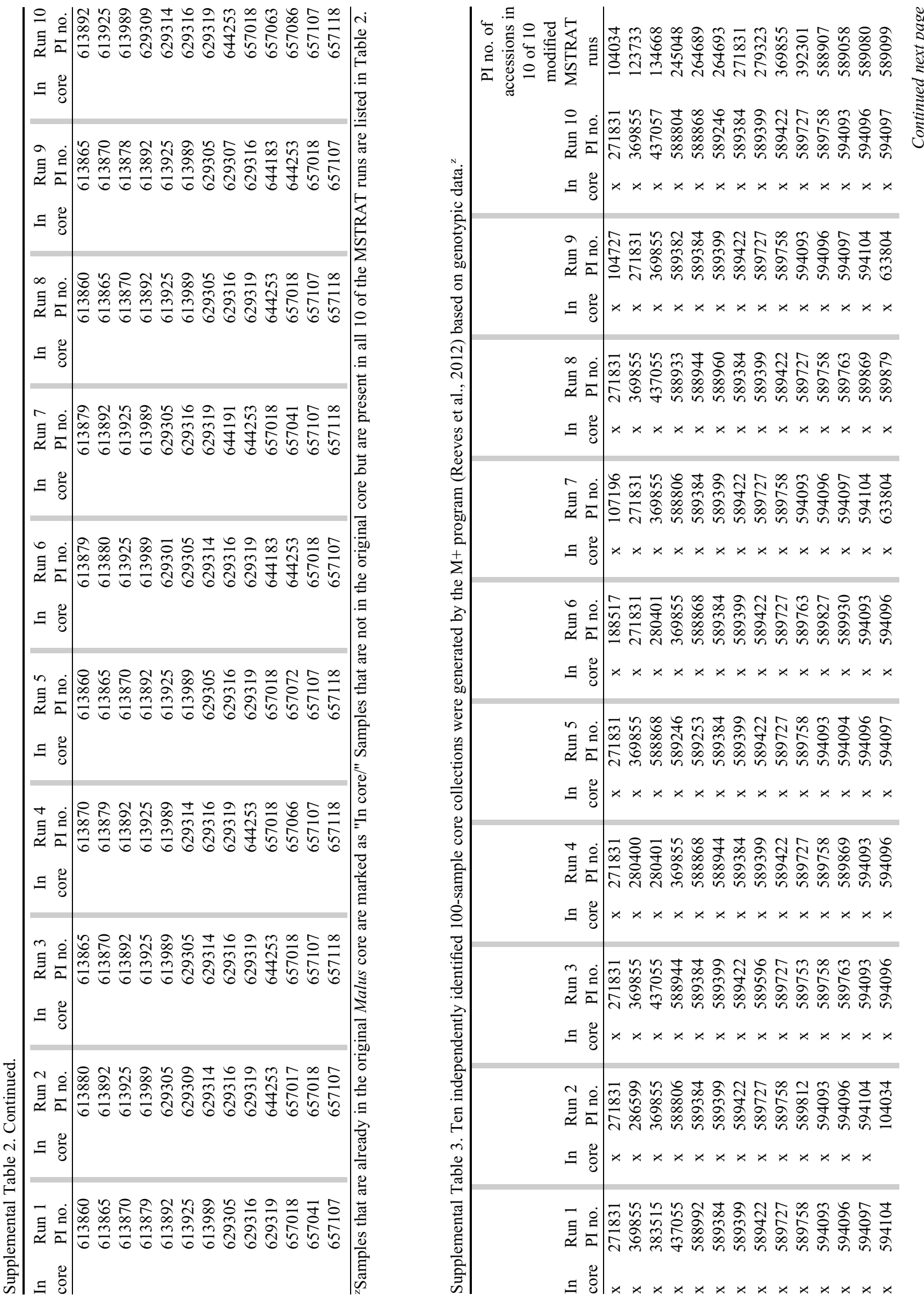


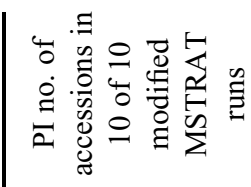

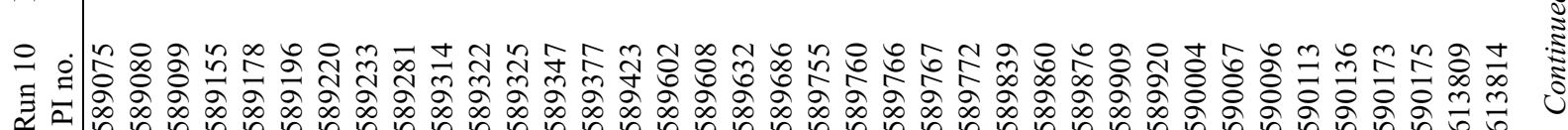

$$
\begin{aligned}
& \Xi \stackrel{0}{0}
\end{aligned}
$$

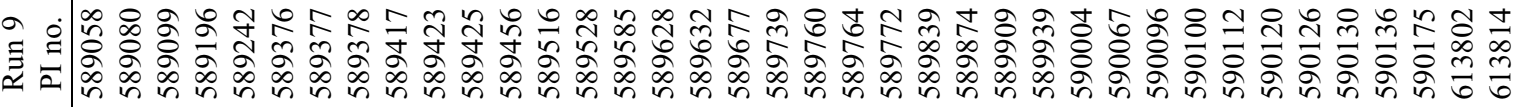

$$
\begin{aligned}
& \Xi \stackrel{0}{0}
\end{aligned}
$$

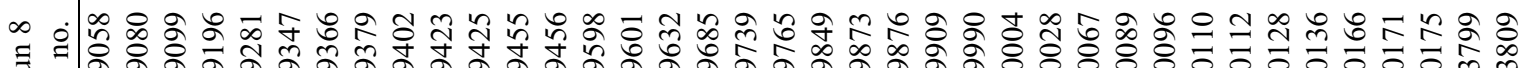

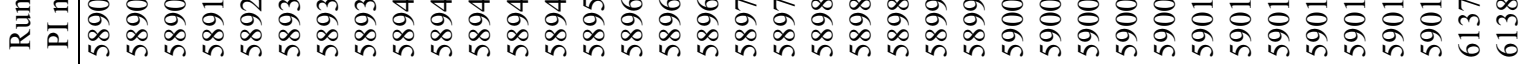

$$
\begin{aligned}
& \Xi \stackrel{0}{0} \\
& \text { ‡: }
\end{aligned}
$$

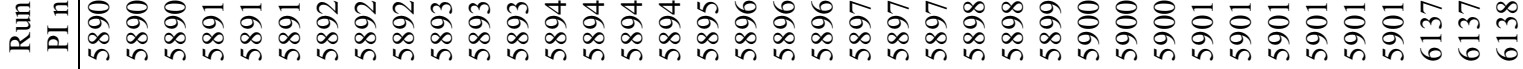

$$
\begin{aligned}
& \Xi \stackrel{0}{0} \\
& \text { 它 }
\end{aligned}
$$

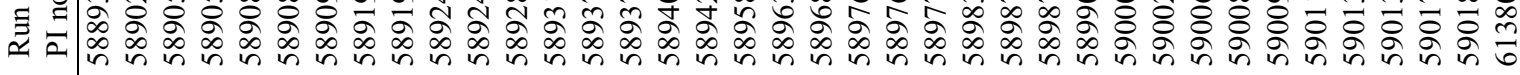

$$
\begin{aligned}
& \Xi \stackrel{0}{0}
\end{aligned}
$$

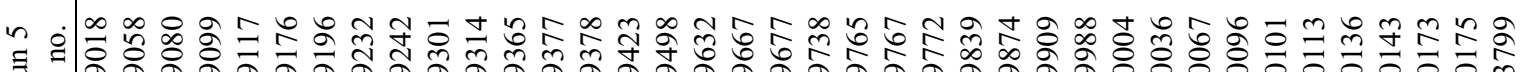

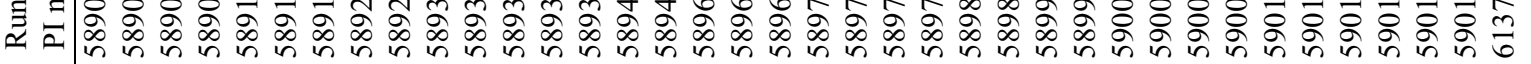

$$
\begin{aligned}
& \Xi \check{\check{\delta}} \\
& \text { † }
\end{aligned}
$$

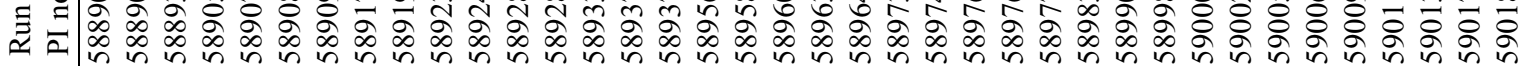

$$
\begin{aligned}
& \Xi \check{\check{\delta}} \\
& \text { m }
\end{aligned}
$$

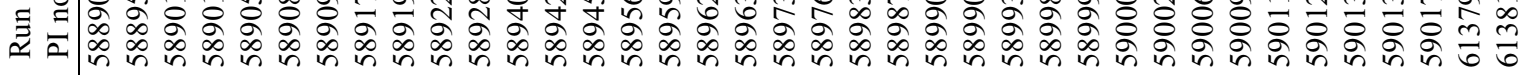

$$
\begin{aligned}
& \Xi \stackrel{0}{0} \\
& \text { ข }
\end{aligned}
$$

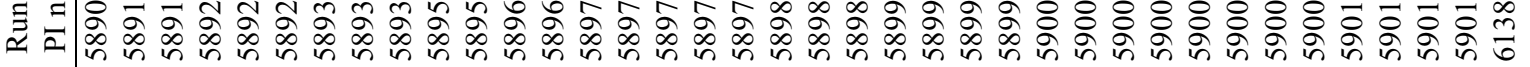

$$
\begin{aligned}
& \Xi \stackrel{0}{0}
\end{aligned}
$$

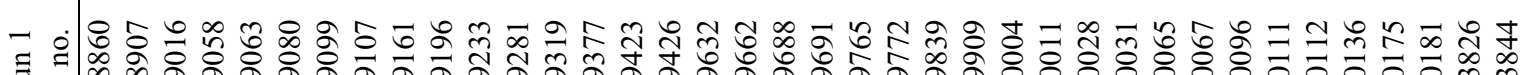

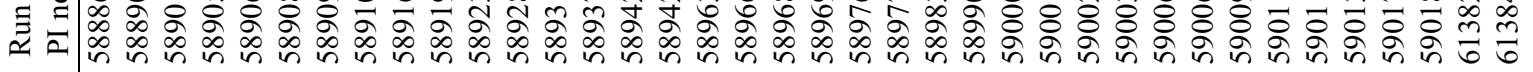

$$
\begin{aligned}
& \Xi \check{\check{o}}
\end{aligned}
$$




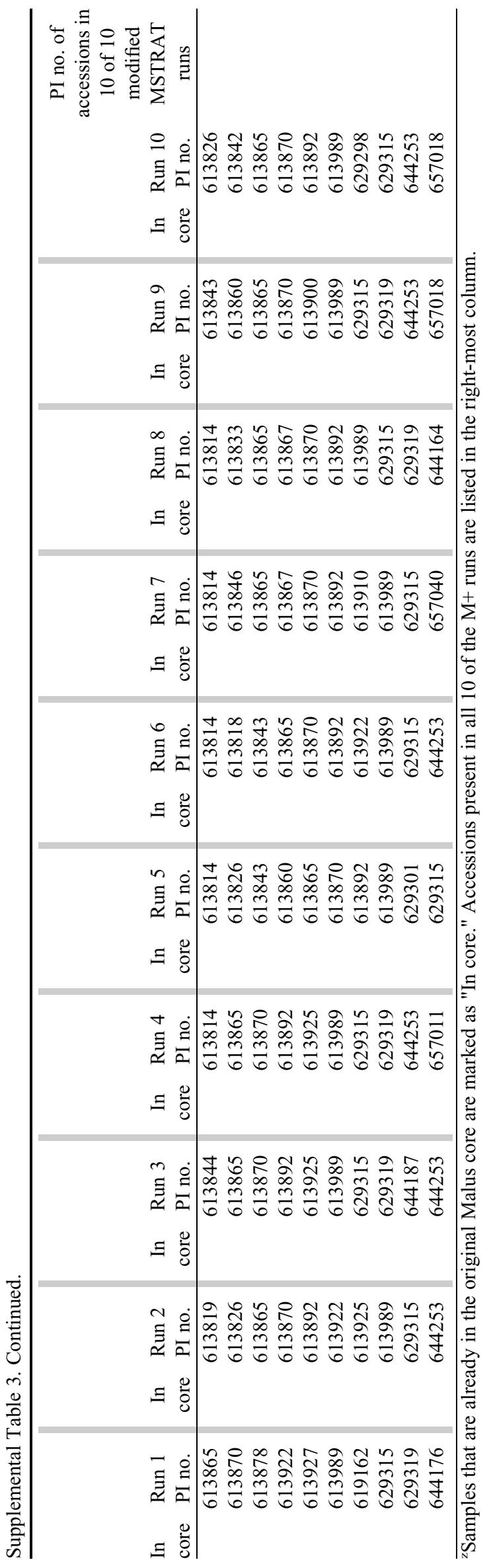

